\title{
Antiviral Properties of Polyphenols from Plants
}

\author{
Katarzyna Chojnacka, Dawid Skrzypczak, Grzegorz Izydorczyk * ${ }^{0}$, Katarzyna Mikula, Daniel Szopa \\ and Anna Witek-Krowiak (D)
}

check for updates

Citation: Chojnacka, K.; Skrzypczak, D.; Izydorczyk, G.; Mikula, K.; Szopa, D.; Witek-Krowiak, A. Antiviral Properties of Polyphenols from Plants. Foods 2021, 10, 2277. https:// doi.org/10.3390/foods10102277

Academic Editor: Maria Cecilia do Nascimento Nunes

Received: 20 July 2021

Accepted: 21 September 2021

Published: 26 September 2021

Publisher's Note: MDPI stays neutral with regard to jurisdictional claims in published maps and institutional affiliations.

Copyright: (c) 2021 by the authors. Licensee MDPI, Basel, Switzerland. This article is an open access article distributed under the terms and conditions of the Creative Commons Attribution (CC BY) license (https:/ / creativecommons.org/licenses/by/ $4.0 /)$.
Department of Advanced Material Technologies, Faculty of Chemistry, Wrocław University of Science and Technology, Smoluchowskiego 25, 50-372 Wrocław, Poland; katarzyna.chojnacka@pwr.edu.pl (K.C.); dawid.skrzypczak@pwr.edu.pl (D.S.); katarzyna.mikula@pwr.edu.pl (K.M.); daniel.szopa@pwr.edu.pl (D.S.); anna.witek@pwr.edu.pl (A.W.-K.)

* Correspondence: grzegorz.izydorczyk@pwr.edu.pl

\begin{abstract}
Polyphenols are active substances against various types of viral infections. Researchers have characterized methods of how to isolate polyphenols without losing their potential to formulate pharmaceutical products. Researchers have also described mechanisms against common viral infections (i.e., influenza, herpes, hepatitis, rotavirus, coronavirus). Particular compounds have been discussed together with the plants in the biomass in which they occur. Quercetin, gallic acid and epigallocatechin are exemplary compounds that inhibit the growth cycle of viruses. Special attention has been paid to identify plants and polyphenols that can be efficient against coronavirus infections. It has been proven that polyphenols present in the diet and in pharmaceuticals protect us from viral infections and, in case of infection, support the healing process by various mechanisms, i.e., they block the entry into the host cells, inhibit the multiplication of the virus, seal blood vessels and protect against superinfection.
\end{abstract}

Keywords: polyphenol; antiviral properties; polyphenols isolation; polyphenols determination

\section{Introduction}

Since time immemorial, plants have been sources of valuable bioactive substances used worldwide to treat various diseases. Isolation and characterization of compounds present in herbs has contributed to the discovery of new sources of pharmaceuticals. About $11 \%$ of essential drugs available globally come exclusively from plants [1]. Contrary to their synthetics, natural preparations are anti-inflammatory, antioxidant, and anticancer in different ways and they are safer for patients because they have no side effects [2].

Polyphenols-secondary plant metabolites that constitute a group of over 8000 structural variants-are of great interest in this respect. Depending on the number of rings and elements connecting these rings, they are classified as flavonoids, phenolic acids, stilbenes or lignans [3]. Pérez-Jiménez et al. (2010) identified the top 100 dietary sources of polyphenols: spices, fruits, seeds, vegetables, drinks and oils. Most of these bioactive compounds are found in cloves $(150 \mathrm{mg} / \mathrm{g})$ and peppermint $(112 \mathrm{mg} / \mathrm{g})$. The polyphenol content in fruits (red raspberry, blackberry, strawberry, apple) ranges from 1.5 to $3 \mathrm{mg} / \mathrm{g}$ of fresh weight. Vegetables rich in bioactive compounds include black or green olives $(5.69 \mathrm{mg} / \mathrm{g}$ and $3.46 \mathrm{mg} / \mathrm{g}$, respectively), artichokes $(2.6 \mathrm{mg} / \mathrm{g})$ and chicory $(2.35 \mathrm{mg} / \mathrm{g})$. Tea (black $102 \mathrm{mg} / 100 \mathrm{~mL}$, green $89 \mathrm{mg} / 100 \mathrm{~mL}$ ), red wine $(101 \mathrm{mg} / 100 \mathrm{~mL}$ ) and rapeseed oil $(92 \mathrm{mg} / 100 \mathrm{~mL})$ can also be sources of polyphenols [4]. Some of the many factors that determine the content of bioactive compounds are light exposure, soil and climatic conditions, type of cultivation (greenhouses, fields, biological or hydroponics), maturity during harvest, storage and processing (e.g., peeling, cooking) [5].

In vitro and in vivo tests show that polyphenols support anti-inflammatory functions and the human body's defense by modulating immune regulation and inhibiting cytokine storms; they also inhibit proinflammatory cytokines, model cellular immunity and act 
as immunomodulators. They act as free radical scavengers in which they are aided by micronutrients and vitamins. All the desirable effects depend on their bioavailability and the amount consumed [6].

New and mutating viruses require new pharmaceuticals. Especially, during the ongoing COVID-19 pandemic and due to the lack of efficient treatment, scientists are trying to develop new preparations to inhibit the penetration and replication of pathogens from the coronavirus family, especially the spread of SARS-CoV-2 (severe acute respiratory syndrome) [7]. Having collected data from scientific sources, patents and clinical trials, Song et al. (2021) have shown that Chinese herbal medicines (mixtures containing, among others, ginger, ginkgo, sage) can block the enzymatic activity of 3CLpro [8]. Acorns and their extracts can also inhibit SARS-CoV-2 replication due to high concentrations of gallic acid [9]. Indian herbs commonly used as food or nutraceuticals (turmeric, nettle, garlic, sage, aloe and black tea) also show activity against virus RNA [10].

Below, we report up-to-date literature on the potential antiviral activity of polyphenols isolated from plants (terrestrial and aquatic), emphasizing the mechanisms and biological basis of these compounds. We know of no publications detailing the mechanisms of action of polyphenols and their impact on the course of viral infections, not only coronaviruses but also influenza, herpes, Epstein-Barr hepatitis, rotavirus and adenovirus. Later in the text, we discuss the latest methods enabling the effective isolation of polyphenols from plants and their identification techniques.

\section{Polyphenol Effectiveness against Viral Infections}

\subsection{Influenza Viruses}

Influenza is caused by RNA Orthomyxoviridae viruses containing an envelope with two glycoproteins (hemagglutinins (HA) and neuraminidase (NA)) and an ion channel (M2). Viruses are divided into A, B, C and D types. Type A is divided into subtypes based on the nature of two proteins on the virus surface: HA and NA [11]. The influenza virus predominantly attacks the respiratory system, causing its failure and numerous complications in the form of bacterial infections. Periodically reoccurring influenza epidemics are responsible for a large percentage of deaths [12]. Frequent mutations of the virus make vaccines ineffective. The emergence of strains that are resistant to antiviral drugs, ion channel inhibitors (e.g., amantadine) and NA inhibitors (e.g., oseltamivir) compels us to look for alternative compounds. Influenza leads to oxidative stress, which-if uninhibited by antioxidants_-produces large amounts of free radicals, damaging lung tissue [13]. Phytotherapy exploits the natural antioxidants which are food components of fruits and vegetables (vitamin C, polyphenols, carotenoids) [14]. Polyphecatechnols, which are primary components of fruits and beverages (green tea, wine), can be used to prevent and treat influenza, as demonstrated in many in vitro and in vivo studies.

Berries are a rich source of various bioactive compounds with antiviral activity [15]. Black elderberry, Sambucus nigra, is an ingredient of Sambucol preparation with proven anti-influenza efficacy [16]. Blackcurrant extracts, apart from inhibiting adsorption and replication of the virus, reduce the formation of complications, including inhibition of other pathogenic microorganisms [17]. Blueberries and cranberries have strong antiviral effects due to the presence of polyphenols [18].

Aronia melanocarpa ethanol extract contains antiviral polyphenols (like ellagic acid) and flavonoids (like myricetin, kaempferol and quercetin). Compounds isolated from chokeberry showed high anti-influenza efficacy: even an amount of $0.0625 \mathrm{mg}$ inhibited almost $70 \%$ of seasonal influenza viruses of $\mathrm{H} 1$ and $\mathrm{H} 3$ type. Aronia extract is most likely to inhibit virus surface proteins (mainly HA) [12].

Polyphenols extracted from the brown alga Ecklonia cava are rich in phlorotannins (including phloroglucinol, ecol, 7-phloracol, fluorofucofuroecol and diecol) and appear to be a selective NA inhibitor of the influenza virus. The ethanolic extract showed very strong NA inhibitory activity $(72.1 \%$ inhibition at $30 \mu \mathrm{g} / \mathrm{mL})$. The $\mathrm{IC}_{50}$ for phlorofucofuroeckol was $4.5 \mu \mathrm{M}$, which was the highest of all components. NA is an important target for 
antiviral agents. The inhibition of this enzyme causes viruses to aggregate, which stops the progression of infection [19].

The ethanolic extract of the aerial roots of Geranium sanguineum has been used in folk medicine to treat various infections. It contains a high amount of phenolic compounds (35\% soluble), especially tannins, flavonoids, catechins and proanthocyanidins type A and B (A-PAC, B-PAC). Studies on mice have shown that these compounds significantly affect liver metabolism, reducing the effects of oxidative stress during influenza virus infection [13].

The polyphenols present in the aerial parts of Eupatorium perfoliatum, isolated in wateralcohol extract, effectively treat influenza. Their activity is associated with blocking the attachment of the virus to the cell surface [20].

The juice and seeds of Morus alba contain a number of polyphenols. Cyanidin-3rutinoside (nearly $30 \mathrm{mg} / \mathrm{g}$ ), cyanidin-3-glucoside, rutin and gallic acid have been identified in the juice. Aqueous and alcoholic extracts exhibit inhibitory activity against the H1N1 influenza virus in a dose-dependent manner. Presumably, the active compounds inhibit viral attachment to cells or affect the inhibition of viral entry into cells [11].

Pomegranate fruit is a traditional remedy with a range of health benefits. The main active compounds are polyphenols: tannins and flavonoids. It is hypothesized that polyphenols bind to virus surface glycoproteins, which changes the molecular structure of these proteins and thus antigenic determinants [21].

\subsection{Hepatitis Viruses}

Five types of viruses cause hepatitis, its attendant complications and chronic liver disease, most commonly hepatitis A virus (HAV), hepatitis B virus (HBV) and hepatitis $C$ virus $(\mathrm{HCV})$. Depending on the type, the viruses are transmitted by food, sex organs and blood, and may also cause co-infections. Vaccines against these viruses are not widespread. Treatment consists of administering immunomodulators (interferon) or nucleoside and nucleotide analogs, which can cause several side effects or result in drug resistance [22]. New antiviral strategies based on natural compounds are being sought. Non-cytotoxic compounds at doses of $2.5-50 \mu \mathrm{g} / \mathrm{mL}$ have been tested in vitro as novel HBV inhibitors. Maximum inhibition of HBsAg antigen on day 5 was obtained for quercitin (73\%) [23]. Studies show that quercetin inhibits genome replication in human cells, and coincubation with nucleo-side analogs (lamivudine, entecavir, or adefovir) enhances quercetin's efficacy against HBV [24].

Green tea polyphenols, particularly epigallocatechin and epigallocatechin-3-gallate (EGCG), epicatechin and epicatechin gallate (ECG), have antiviral activity. Specifically, EGCG, which represents half of the green tea polyphenol fraction, has broad inhibitory activity against various viruses, including hepatitis. This compound has been shown to inhibit HCV's entry into cells via viral envelope proteins and inhibit cell-to-cell transmission [25]. The $\mathrm{IC}_{50}$ inhibitory concentration is $5 \mu \mathrm{m}$ and the $\mathrm{IC}_{90}$ inhibitory concentration is approximately $50 \mu \mathrm{m}$ for recombinant HCV (JFH1-Luc). The compound can be coupled with other antiviral drugs [26]. Theaflavins in black tea also have an inhibitory effect on HCV by acting directly on the virus before it enters cells [27]. Tannic acid, present in many plants, has a similar effect and has been shown to inhibit Huh7.5 cell entry at an $\mathrm{IC}_{50}$ concentration of $5.8 \mu \mathrm{M}$ [28].

The main mechanism of antiviral action of EGCG is inhibition of DNA synthesis during HBV replication [29]. This compound's effect, which is strongly dose-dependent, was observed at concentrations of $0.11-0.44 \mu \mathrm{mol} / \mathrm{mL}$ for HepG2 2.2.15 cells compared to the drug lamivudine $(0.87 \mu \mathrm{mol} / \mathrm{mL})$ [30]. Most studies on the antiviral activity of polyphenols involve in vitro or cell line studies. Clinical trials are needed to evaluate the efficacy of these compounds and to select a therapeutic dose.

The antioxidant resveratrol is responsible for activating the longevity gene (sirtuin). Due to it, consumption of red wine is considered beneficial. It is known that resveratrol is recommended as an adjunctive supplement to the treatment of chronic HCV. However, 
cellular studies have examined the antioxidant's effect on the antiviral effects of interferon and have reported that resveratrol is not recommended as a supplement in antiviral therapy because it significantly enhances virus replication [31]. Similarly, in the case of HBV virus, resveratrol strongly affects the core promoter and enhances transcription and replication of the virus [32]. Studies have also demonstrated that resveratrol multimers strongly inhibit HCV replication. Resveratrol dimers $((+)-\varepsilon$-viniferin) extracted from grapevine root and chemically synthesized (with or without acetylation) were found to be a promising group of novel anti-HCV drugs with minimal cytotoxicity [33].

Curcumin as a natural compound has antiviral properties and it can be used to treat HBV patients by targeting cellular and metabolic pathways (adhesion molecule, protein kinases, inflammatory cytokine, transcription factors, anti-apoptotic proteins). Curcumin can activate PPAR $-\gamma$ receptor in adipose tissue, increase cellular glutathione content and modify the level of PGC-1 $\alpha$ protein that regulates gluconeogenesis in the liver, leading to downregulation of transcription factor NF- $\mathrm{KB}$ [34].

Cellular studies have confirmed the effectiveness of curcumin in inhibiting HBV expression. A dose of $20 \mu \mathrm{mol} / \mathrm{L}$ curcumin applied for 2 days reduced HBsAg antigen levels to 57.7\% [35]. Animal studies (rats, guinea pigs, monkeys) have shown that curcumin is safe in most cases. In clinical studies (25 subjects), $8000 \mathrm{mg}$ of curcumin was dosed daily and no toxic effects of the substance were observed [34].

\subsection{Herpes Virus}

The herpes virus belongs to the Herpesviridae family, which also includes Epstein-Barr, cytomegalovirus and varicella zoster viruses. This virus has a double-stranded DNA and is an enveloped virus that, once inside, cannot be removed from the body and enters the cells of the nervous system, where it can survive asymptomatically for many years. When exposed to unfavorable conditions (stress, immunodeficiency), it becomes active and again manifests disease symptoms. The most common are herpes simplex virus 1 (HSV-1), which causes infections around the mouth, and herpes simplex virus 2 (HSV-2), responsible for infections of reproductive organs [36]. The most common drugs against this virus are nucleoside analogs, such as acyclovir, which inhibits DNA polymerase.

Active components of hibiscus extracts show potent activity against the HSV-1 virus, indicating the blockade of virus replication and prevention of virus-cell interaction in vitro [37]. Similarly, the tea polyphenol EGCG inhibits the cytotoxic effect of the virus on cell viability and viral protein expression in amounts as low as $25 \mu \mathrm{g} / \mathrm{mL}$. This may be due to the effects of polyphenols on virions before they enter the cell [38]. Polyphenolic extracts of pistachio kernels showed synergistic effects of all the components with antiviral properties. The antiviral activity of $\mathrm{EC}_{50}$ against $\mathrm{HSV}-1$ was in the amount of $0.4 \mathrm{mg} / \mathrm{mL}$ in plaque assay [39]. The strong anti-herpes activity was proven for plant extracts from Euphorbia coopire $\left(\mathrm{EC}_{50} 36 \mathrm{ng} / \mathrm{mL}\right)$ and Morus alba $\left(\mathrm{EC}_{50}>50 \mu \mathrm{g} / \mathrm{mL}\right)$, in which several flavonoid compounds were found, including quercetin [40].

Silver nanoparticles stabilized with tannic acid may be an effective agent against genital herpes. The antiviral nature of both plant extracts and nanoparticles is exploited here, indicating a multidirectional mechanism of action associated with blocking virus attachment and producing compounds with anti-HSV-2 activity (cytokines, chemokines) [41].

\subsection{Epstein-Barr Virus}

A high percentage of the population carries Epstein-Barr virus but shows no symptoms of the infection throughout their lives. Infectious mononucleosis, caused by this virus, mainly affects teenagers and young adults, mostly immunocompromised individuals [42]. In AIDS patients, Epstein-Barr virus can cause hairy leucoplakia of the tongue. The virus has also been associated with malignancies such as Burkitt's lymphoma, Hodgkin's lymphoma and nasopharyngeal carcinoma [43]. The main targets of the virus are resting B lymphocytes, which are induced to proliferate by the virus. The viral cycle allows the horizontal spread of the virus and promotes the development of B-cell nodules [44]. 
Treatment of individuals with symptoms of virus infection mainly involves the use of pharmacotherapy and, in more complex cases, chemotherapy or radiation. The use of antiviral compounds is associated with a high likelihood of side effects. In most cases, such drugs have poor bioavailability, which limits their impact [45].

The literature has shown that some polyphenols have properties that inhibit the expression of Epstein-Barr Virus lytic genes [46]. An investigation was conducted into the antiviral activity of resveratrol, a polyphenol contained in many plant species and their fruits (blackcurrant, strawberries, raspberries, mulberries or grapes). Resveratrol is a bioflavonoid compound that exhibits antibacterial, antifungal, anticancer and antioxidant properties [47]. Resveratrol significantly inhibits the expression of virus lytic genes. The inhibition of its reproduction is strictly dependent on the dose of polyphenol. Resveratrol decreases levels of reactive oxygen species, blocks protein synthesis and inhibits virusinduced activation of transcription factors, which affects Epstein-Barr virus replication in individuals [42]. Among a large group of polyphenols, high effectiveness against EpsteinBarr virus is reported for luteolin, which is used to treat hypertension and inflammatory disorders in Chinese medicine. The flavonoid was tested for its ability to inhibit virus reactivation. Luteolin stops the expression of proteins from lytic genes and B EBV-positive cells. Additionally, the study showed reduced viral production and a reduced number of virus reactivating cells [48].

Literature data present a method of synthesis of new polyphenols based on esters consisting of naturally occurring materials: ferulic acid (mainly from rice and wheat) and gallic acid (from a commercial basis) [49]. Studies have been carried out on the inhibitory effect of polyphenol on 12-tetradecanoylphorbol-13-acetate, which activates the Epstein-Barr virus. The authors successfully demonstrated the effectiveness of the new polyphenols. The production of ferulic acid (from rice bran) and gallic acid is already commercialized, theoretically allowing for broader manufacturing and use of high-activity antiviral preparation. Components of natural origin are also being used as building blocks to produce biocompatible forms to treat the Epstein-Barr virus. A nanovaccine has been prepared from tannic acid and a novel protein antigen to fight virus-associated cancer. The polyphenol, as a plant-derived material, self-organizes with antigens and adjuvants to form an effective nanoparticle vaccine. Nanovaccine, targeting lymph nodes, together with CpG adjuvant, causes immune activation. This induces effective inhibition of oncogenesis. In studies on mice, it has been shown that the application of the agent also results in a decrease in the tumor and an increase in the lifespan of the rodents [50].

\subsection{Rotavirus}

Rotavirus is a non-motile virus that contains a multilayered virion that consists of 11 RNA segments. This virus is a major pathogen that causes gastroenteritis and acute diarrhea, which leads to dehydration. As many as 200,000 deaths per year are caused by rotavirus infection. Available information indicates no clear evidence of the presence of an effective treatment for the infected individual. Recovery is mainly based on replenishing fluids and electrolytes. The duration of the infection can be shortened by probiotics [51]. The global rotavirus problem can be reduced with the two available vaccines (Rotarix and RotaTeq), but the live form of the vaccines, the high risk of transmission and variations in efficacy limit their application [52].

Polyphenols isolated from the roots of Glycyrrhiza uralensis plants inhibit rotavirus from binding with cells and replicating. This effect of extracted polyphenols (licocoumarone, 2 '-methoxyisoliquiritigenin, glyasperin C, glycyrin, licoflavono and glyasperin D) on rotavirus of the G5P and G8P group has been proven in vitro tests. It has been shown that resveratrol at a dose of $20 \mu \mathrm{M}$ inhibits rotavirus replication in the Caco-2 cell line [52]. The bioflavonoid inhibits RNA synthesis, protein expression or the formation of viroplasmic plaques. Research on mice treated with resveratrol showed that the agent reduced diarrhea's severity and alleviated other symptoms [53]. High antiviral activity was also 
confirmed for Myracrodruon urundeuva leaves. Plant extracts were tested for inhibition of monkey rotavirus SA-11, showing 75-92\% virucidal effect [54].

Achyrocline bogotensis, grown in Colombia, is widely used for the treatment of skin, respiratory and urinary tract infections. The high anticancer activity of flavonoids obtained from this plant has also been proven in some papers. A C6-C3-C6 phenylbenzopyrone backbone characterizes a large proportion of these compounds. The efficacy of extracts derived from Achyroklina bogotensis was tested in treating viral gastrointestinal diseases caused by rotavirus and astrovirus [55]. The study confirmed high antiviral and antimicrobial efficacy. Anti-inflammatory and antiviral effects were also demonstrated by Sophora flavescens root extract containing the flavone norkurarinol. Norkurarinol suppresses the mRNA expression of proinflammatory and adhesion molecules caused by poly(I:C) and rotavirus infection. In addition, the flavonoid inhibits cytoplastic effects induced by rotainfection. Norkurarinol modulates inflammatory responses mediated by toll-like receptor 3 and rotavirus proliferation [56].

\subsection{Coronavirus}

The potential of polyphenols was underlined during the SARS-CoV-2 pandemic because they present multiple defense mechanisms against coronaviruses. This is a group of RNA viruses transmitted mainly by birds and mammals. The name derives from the image of the virus obtained under the electron microscope, in which the "crowns" of the virus envelope are visible. The best-known viruses are SARS-CoV-1 and SARS-CoV-2, responsible for severe acute respiratory syndrome (SARS) [57].

The effect of polyphenols on coronavirus infections is complex. First of all, selected polyphenols-e.g., luteolin — show a high affinity with the $S$ protein of the virus, thus preventing its entry into human cells [58]. Inhibition of the $S$ protein is mainly caused by polyphenols present in citrus fruits, turmeric and rhubarb roots. Other scientific sources mention the possibility of blocking protein $S$ by active compounds contained in herbs and tea-naringenin, EGCG or herbacetin [59]. Entry into host cells is also blocked by blocking the enzyme ACE2, which is the entry point of SARS-CoV-2. Polyphenols in turmeric, yerba and red grapes (eriodicytol, resveratrol, curcumin and catechin), which have a high affinity for ACE2 ligands, are beneficial for this purpose [60].

After the virus enters the human body with the help of polyphenols, its multiplication by RNA replication is blocked. Actions are mainly directed at protease inhibition, thus blocking transcription and replication of genetic material. Here also the role of polyphenols from turmeric and citrus fruits has been appreciated [60]. On the other hand, the polyphenols EGCG, myricetin and quercetagetin show a high affinity for SARS-CoV-2 RdRp, an RNA polymerase that produces an RNA strand on the matrix [61].

The incidence of the population SARS-CoV-2 virus depends on exposure to its vectors and the condition of the immune system. With the onset of the current pandemic, attention was paid to the need for immune stimulation with vitamins $C$ and $D$, zinc and cod liver oil [62]. The potential of polyphenols has also been highlighted due to their antioxidant properties and their ability to seal blood vessels. This induces anti-inflammatory mechanisms, especially through the inhibition of proinflammatory cytokine synthesis. Literature data report that polyphenols in green tea, grapes, berries, citrus and curcumin are recommended for coping with coronavirus infections $[63,64]$. The most commonly mentioned are resveratrol, EGCG, heaflavin-3-O-gallate, oolonghomobisflavan-A and theasinensin-D [62].

The issue of coronavirus nowadays is of serious concern. The analysis of scientific databases has revealed many literature reviews describing the effects of polyphenols as antiviral antioxidants that support the immune system $[8,57-60,65-68]$. 


\section{Mechanism of Antiviral Activity}

The purpose of Table 1 is to show the recent research trends in the use of natural sources of polyphenols in suppressing viruses. The information focuses on determining the composition of natural compounds in polyphenols and the mechanism of their synergetic action on virus cells. The mechanism behind the inhibition by polyphenol extracts depends on the type of virus and the origin of a given compound. Herpes simplex virus (HSV-1, HSV-2) inhibition is strongly related to the NS3 protease; as for the influenza virus, it is related to the effect on the ectodomain of viral HA or inhibiting NA activity. However, the mechanism can vary significantly depending on whether we are dealing with a single polyphenol compound or an extract containing several polyphenol groups and other nonpolyphenol substances $[69,70]$. Most of the studies mentioned in Table 1 indicate that antiviral activity occurs by inhibiting the virus replication or limiting the virus replication in the early stages of infection. Some suggest using polyphenols in the preventive form, which allows blocking viral entry and progeny virion release. It is currently impossible to determine how a given polyphenol or a group of compounds will react to various viruses, as there is still little information about their mechanism. Intensive research in this area is required.

Many studies, e.g., [41,69,71-73], deal with a question of the synergistic effect of polyphenolic compounds and non-polyphenols, which individually show no or much lower antiviral properties, but together can inhibit the life cycle of viruses efficiently. One study [74] showed an interesting application of tannic acid as a substance used in the production of HEPA filters, which prevented the influenza virus infection unconventionally. Nevertheless, polyphenols are not only used against human viruses. Many studies describe the effect of various polyphenols on the tobacco mosaic virus, which suggests that polyphenols might be applied in the treatment of viruses affecting plants. Additionally, those compounds show antiviral activity against animal viruses, as demonstrated in [75], which describes the property of proanthocyanidin A2 (PA2) inhibiting the spread of porcine reproductive and respiratory syndrome (PRRS).

The most common polyphenols are catechin, tannic acid, gallic acid, resveratrol, EGCG and various types of kaempferol and quercetin. Most of the information on the inhibition mechanism of different viruses of the same compound is related to each other. That tendency indicates a similar behavior of these compounds in various types of configurations. However, these mechanisms have not been thoroughly investigated and are mostly the author's hypotheses derived from his research. References [69-72] focus on describing the effect and doses of given natural compounds for virus suppression. These papers indicate the need to research the mechanism and composition of the compounds listed in Table 1 for the possibility of practical use because these works do not contain information on the mechanism of inhibition. Many papers do not describe in detail the mechanism of action of individual polyphenols. Instead, refs. [34,62-64,73] show a possibility of a synergistic effect of polyphenol and non-polyphenol compounds on virus cells, which does not occur in individual applications or is significantly weaker compared to complex use in the form of, e.g., natural extracts.

Presented papers indicate new ways of research that can expand the application of polyphenols in farming and agriculture. Attention should be paid to the synergistic effect of polyphenols, possibly enhancing their basic antiviral properties and suggesting new applications. 
Table 1. Antiviral activity of different polyphenols extracted from plants.

\begin{tabular}{|c|c|c|c|c|c|}
\hline Material & Polyphenols & Virus & Dose & Mechanism & References \\
\hline $\begin{array}{l}\text { mulberry (Morus alba) } \\
\text { juice }\end{array}$ & $\begin{array}{c}\text { caffeic acid, } \\
\text { chlorogenic acid, } \\
\text { p-coumaric acid, } \\
\text { cyanidin-3-glucoside, } \\
\text { cyanidin-3-rutinoside, } \\
\text { 3,4-dihydroxybenzoic acid, } \\
\text { gallic acid, } \\
\text { rutin }\end{array}$ & $\begin{array}{c}\text { IAV, IBV variety } \\
\text { (A/Brisbane/59/2007- [H1N1, BR59], } \\
\text { A/Korea/01/2009-[H1N1, KR01], } \\
\text { A/Brisbane/10/2007-[H3N2, } \\
\text { BR10], B/Florida/4/2006 [FL04]) }\end{array}$ & $\begin{array}{l}\text { mulberry juice at } 2 \% \text { and } 4 \% \text { exhibited } 1.3 \log \\
\text { inhibition on FL04 virus in the pretreatment and } \\
\text { cotreatment of the virus }\end{array}$ & $\begin{array}{l}\text { antiviral activity at the initial stage of the } \\
\text { virus inhibits the attachment of viral surface } \\
\text { protein to its cellular receptor or due to } \\
\text { internalization of cell surface receptors from } \\
\text { virions and prevents virus adsorption to } \\
\text { host cells }\end{array}$ & [11] \\
\hline black tea & $\begin{array}{l}\text { theaflavin (TF1), } \\
\text { theaflavin-3'-monogallate(TF2), } \\
\text { theaflavin-3-3'-digallate(TF3) }\end{array}$ & $\mathrm{HCV}$ & 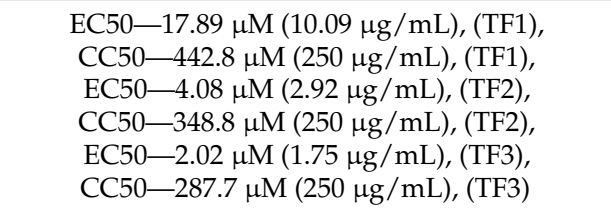 & $\begin{array}{l}\text { polyphenols prevent cell surface } \\
\text { attachment or receptor binding by acting on } \\
\text { viral particles and thus inhibiting the } \\
\text { cell-to-cell spread }\end{array}$ & [25] \\
\hline $\begin{array}{l}\text { Euphorbia cooperi } \\
\text { (euphorbiaceae), Morus } \\
\text { alba (moraceae) }\end{array}$ & $\begin{array}{l}\text { 1.catechin-7-gallate, } \\
\text { 2. gallic acid, } \\
\text { 3. kaempferol 3-O-(6"-O-galloyl)- } \\
\text { glucopyranoside, } \\
\text { 4. quercetin3-O-(6"-O-galloyl)- } \\
\text { glucopyranoside, } \\
\text { 5. curcumin, } \\
\text { 6. quercetin, } \\
\text { 7. kaempferol }\end{array}$ & HSV-1 & $\begin{array}{c}\text { CC50- }[\mu \mathrm{g} / \mathrm{mL}]: \\
\text { 1. } 43.2 \pm 2.3 \\
\text { 2. } 49.8 \pm 0.4 \\
\text { 3. } 124.1 \pm 1.2 \\
\text { 4. } 175.6 \pm 0.9 \\
\text { 5. } 49.8 \pm 0.4 \\
\text { 6. } 78.1 \pm 0.8 \\
\text { 7. } 76.1 \pm 0.2\end{array}$ & $\begin{array}{l}\text {-the mechanism inhibits viral replication or } \\
\text { viral genome synthesis. HSV-1 employs } \\
\text { glycosaminoglycan (GAG) as initial } \\
\text { attachment receptors during infection of } \\
\text { their host cell, so polyphenols target HSV-1 } \\
\text { glyco-proteins } \\
\text {-this type of interaction prevents the virus } \\
\text { from connecting with binding receptors and } \\
\text { cell surface }\end{array}$ & [33] \\
\hline plant-based polyphenols & $\begin{array}{l}\text { tannic acid with modified silver } \\
\text { nanoparticles (TA-AgNPs) }\end{array}$ & HSV-2 & $\begin{array}{c}5 \mu \mathrm{g} / \text { mouse TA-AgNPs sized } 33 \mathrm{~nm} \text { applied } \\
\text { upon the mucosal tissue }\end{array}$ & $\begin{array}{l}\text {-the mechanism is based on two properties } \\
\text { of used compounds } \\
\text {-one is connected with tannic acid that } \\
\text { interferes with the viral adsorption } \\
\text { mechanism } \\
\text { - second is based on the ability of silver } \\
\text { nanoparticles that can block the attachment } \\
\text { of the virus and its entry } \\
\text {-nanoparticles can also induct antiviral } \\
\text { cytokine and chemokine production } \\
\text {-efficiency of TA-AgNPs of the inactivation } \\
\text { of the virus might depend on the proline } \\
\text { content in HSV glycoproteins }\end{array}$ & [34] \\
\hline
\end{tabular}


Table 1. Cont.

\section{Material}

Polyphenols

Virus curcumin (Cur),

pice and common food

colorant, turmeric
IAV variety (H1N1)

$30 \mu \mathrm{M}$ in MDCK cells for single compound $15 \mu \mathrm{M}$ mixture of polyphenols (7.5 $\mu \mathrm{M}$ Cur and $7.5 \mu \mathrm{M}$ MAC) -both polyphenols initican. Cur and MAC mech viral NA activity, but MAC did not block HA activity, compared to Cur

MAC dampened phosphorylation, which is essential for efficient IAV propagation -replication of IAV in cells is most likely connected with PI3K/AKT activation which is suppressed by MAC

-both polyphenols inhibit IAV separately

but together give better results

based on the type of fraction: CC50 $\geq 200 \mu \mathrm{g} / \mathrm{mL}(1,2,5)$, CC50-149.7 $\pm 3.1 \mu \mathrm{g} / \mathrm{mL}$ (3)

cranberry (Vaccinium macrocarpon aiton) extracts
A-type proanthocyanidins

(A-PAC), dimers and trimer

IAV, IBV
CC50-136.4 $+2.4 \mu \mathrm{g} / \mathrm{mL}(4)$

$$
\text { IC } 50-50 \mu \mathrm{g} / \mathrm{mL}(1,2,5) \text {, }
$$

IC $50-5.02 \pm 1.2 \mu \mathrm{g} / \mathrm{mL}$ (3 IAV)

IC $50-3.24 \pm 1.4 \mu \mathrm{g} / \mathrm{mL}$ ( 4 IAV)

IC $50-6.02 \pm 1.2 \mu \mathrm{g} / \mathrm{mL}$ (3 IBV),

IC50-4.07 $\pm 1.8 \mu \mathrm{g} / \mathrm{mL}$ (4 IBV)

\section{EGCG}

green tea

cranberry plant the nutraceutical CystiCranÒ-40

(containing 40\%), A-PAC, B-PAC) coliphage T4II (phage T4),the

rotavirus strain SA-11(RTV)

\section{mixture of}

$60 \mu \mathrm{g} / \mathrm{mL}$ (EGCG) and $100 \mu \mathrm{g} / \mathrm{mL}(\mathrm{C}-40)$ $30 \mu \mathrm{g} / \mathrm{mL}$ (EGCG) and $25 \mu \mathrm{g} / \mathrm{mL}$ (C-40)

-PAC-A2 achieves the inhibitory effect of polyphenol extract against influenza viruses interacting with the ectodomain of viral HA and the formation of three hydrogen bonds Phe99, Asn210, and Trp234 of H glycoprotein

-those properties affect the HA protein band by reducing its intensity

the combination of those polyphenols is most likely based on blocking or altering viral ligands or antigenic determinants, which reduce the binding ability of

the present publication concludes two options for antiviral activity of the given extract, either the polyphenols are non-flavonoid phenols and/or the antiviral activity is elicited by other types
$\mathrm{IAV}, \mathrm{IBV}$ variety $(\mathrm{A} / \mathrm{PR} / 8 / 34$

H1N1, H3N2 and B)
IC50-2.11-5.13 mg/mL (IAV)

C50-2.91-4.61 mg/mL (IBV) CC50 $\geq 40 \mathrm{mg} / \mathrm{mL}$ the virus

extract most probably consist of phenolic acids (coumaric, ferulic,

Arachis hypogaea (L.) skin, chlorogenic, p-hydrobenzoic A-PACB-PAC), and stilbenes (resveratrol), where resveratrol is the main compound antiviral activity most likely manifests itself in the inhibition of virus adsorption to the cell and its replication, where tea also affects binding to cells directly -the mechanism is probably based on inhibition of replication or its early stages, where a combination of an extract with oseltamivir and amantadine prove to be more effective against the influenza virus this phenomenon is most probably due to 
Table 1. Cont.

\begin{tabular}{|c|c|c|c|c|c|}
\hline Material & Polyphenols & Virus & Dose & Mechanism & References \\
\hline plant-based extract & tannic acid (TA) & IAV variety (H1N1) & $\begin{array}{l}\text { HEPA filter treated with } 5 \mathrm{mg} / \mathrm{mL} \text { of TA for } 2 \mathrm{~h} \\
\text { at } 22 \mathrm{oC}\end{array}$ & $\begin{array}{l}\text { linking TA molecules with HA, which are } \\
\text { present on the influenza virus' surface, } \\
\text { allows their interaction and subsequent } \\
\text { inhibition of viral proteins NA and M2 in } \\
\text { the inner part of the virus }\end{array}$ & [73] \\
\hline $\begin{array}{l}\text { tea polyphenols found in } \\
\text { fruits, nuts and seeds }\end{array}$ & PA2 & PRRS & $\begin{array}{c}\text { EC50-2.2-3.2 } \mu \mathrm{g} / \mathrm{mL} \\
\text { IC50-2.5-3.2 } \mu \mathrm{g} / \mathrm{mL} \text { (Marc-145 cells), } \\
\text { CC50-126.5 (Marc-145 cells) and } 63.9 \text { (PAM } \\
\text { cells) } \mu \mathrm{g} / \mathrm{mL}\end{array}$ & $\begin{array}{l}\text { inhibition consists of blocking viral entry } \\
\text { and progeny virion release, which was } \\
\text { obtained from reducing gene expressions of } \\
\text { cytokines (TNF- } \alpha \text {, IFN- } \alpha \text {, IL-1 } \beta \text {, IL-6) }\end{array}$ & [74] \\
\hline $\begin{array}{l}\text { Ajuga iva (L.) aerial part } \\
\text { extracts }\end{array}$ & $\begin{array}{l}\text { total phenolic content (TPC) } 28.3 \pm 1.12 \\
\text { flavonoids content (FC) } 10.5 \pm 0.83 \\
\text { tannins content (TC) } 7.2 \pm 0.31\end{array}$ & $\begin{array}{l}\text { coxsackie virus type B-3 } \\
\text { (CV-B3) }\end{array}$ & $\begin{array}{l}\text { IC } 50-0.43 \pm 0.03 \mathrm{mg} / \mathrm{mL} \\
\text { AC } 50-182 \pm 12 \mu \mathrm{g} / \mathrm{mL} \\
\text { CC50-2810 } \pm 36 \mu \mathrm{g} / \mathrm{mL}\end{array}$ & - & [75] \\
\hline $\begin{array}{l}\text { Juglans regia, pellicle } \\
\text { extract (WPE) }\end{array}$ & $\begin{array}{l}\text { protocatechuic acid, gallic acid, ellagic } \\
\text { acid, quercetin, myricetin, chlorogenic } \\
\text { acid, kaempferolarabinoside, avicularin, } \\
\text { (+)-procyanidin B2, rutin }\end{array}$ & HSV-1, HSV-2 & $\begin{array}{l}\text { ID50-10 } \mu \mathrm{g} / \mathrm{mL} \text { (HSV-1) } \\
\text { ID50—8 } \mu \mathrm{g} / \mathrm{mL} \text { (HSV-2) }\end{array}$ & - & [76] \\
\hline Cornus canadensis & $\begin{array}{c}\text { 1,6-di-O-galloyl- } \beta \text {-D-glucopyranose, } \\
\text { 1,2,3-tri-O-galloyl- } \beta \text {-D-glucopyranose, } \\
\text { 1,2,6-tri-O-galloyl- } \beta \text {-D-glucopyranose, } \\
\text { 2,3,6-tetra-O-galloyl- } \beta \text {-D- } \\
\text { glucopyranos, } \\
\text { 2,3,4,6-penta-O-galloyl- } \beta \text { - } \\
\text { D-glucopyranose, } \\
\text { tellimagrandin I, } \\
\text { tellimagrandin II, } \\
\text { ethyl gallate, } \\
\text { caffeic acid, } \\
\text { astragalin, } \\
\text { isoquercetin, } \\
\text { trifolin, } \\
\text { kaempferol 3-O- } \beta \text {-D-xylopyranoside, } \\
\text { reinutrin, } \\
\text { juglanin, } \\
\text { avicularin, } \\
\text { juglalin, } \\
\text { k-g-glucopyranosyl-2,6- } \\
\text { hydroxybenzoate, } \\
\text { byzantionoside B }\end{array}$ & HSV-1 & $\begin{array}{c}\text { direct mode } \\
\text { EC50-11-17 } \mu \mathrm{g} / \mathrm{mL} \text { (extract) } \\
\text { EC50-2.6 } \pm 0.1 \mu \mathrm{M} \text { (tellimagrandin I) } \\
\text { EC50-7 } \pm 4 \mu \mathrm{M} \\
\text { EC50-10 } \pm 2 \mu \mathrm{M} \\
(2,3,6 \text {-tetra-O-gal-loyl- } \beta \text {-D-glucopyranose) } \\
(2,3,4,6-\text { penta-O-galloyl- } \beta \text {-D-glucopyranose) } \\
\text { EC50-7 } \pm 1 \mu \mathrm{M} \text { (tellimagrandin II) } \\
\text { absorption mode } \\
\text { EC50-9 } \mu \mathrm{g} / \mathrm{mL} \text { (extract) } \\
\text { EC50—5.0 } \pm 0.2 \mu \mathrm{M} \text { (tellimagrandin I) } \\
\text { EC50-11 } \pm 3 \mu \mathrm{M} \\
(2,3,6 \text {-tetra-O-gal-loyl- } \beta \text {-D-glucopyranose) } \\
\text { EC50-12 } \pm 4 \mu \mathrm{M} \\
\text { (2,3,4,6-penta-O-galloyl- } \beta \text {-D-glucopyranose) } \\
\text { EC50-11 } \pm 3 \mu \mathrm{M} \text { (tellimagrandin II) }\end{array}$ & - & [77] \\
\hline
\end{tabular}


Table 1. Cont

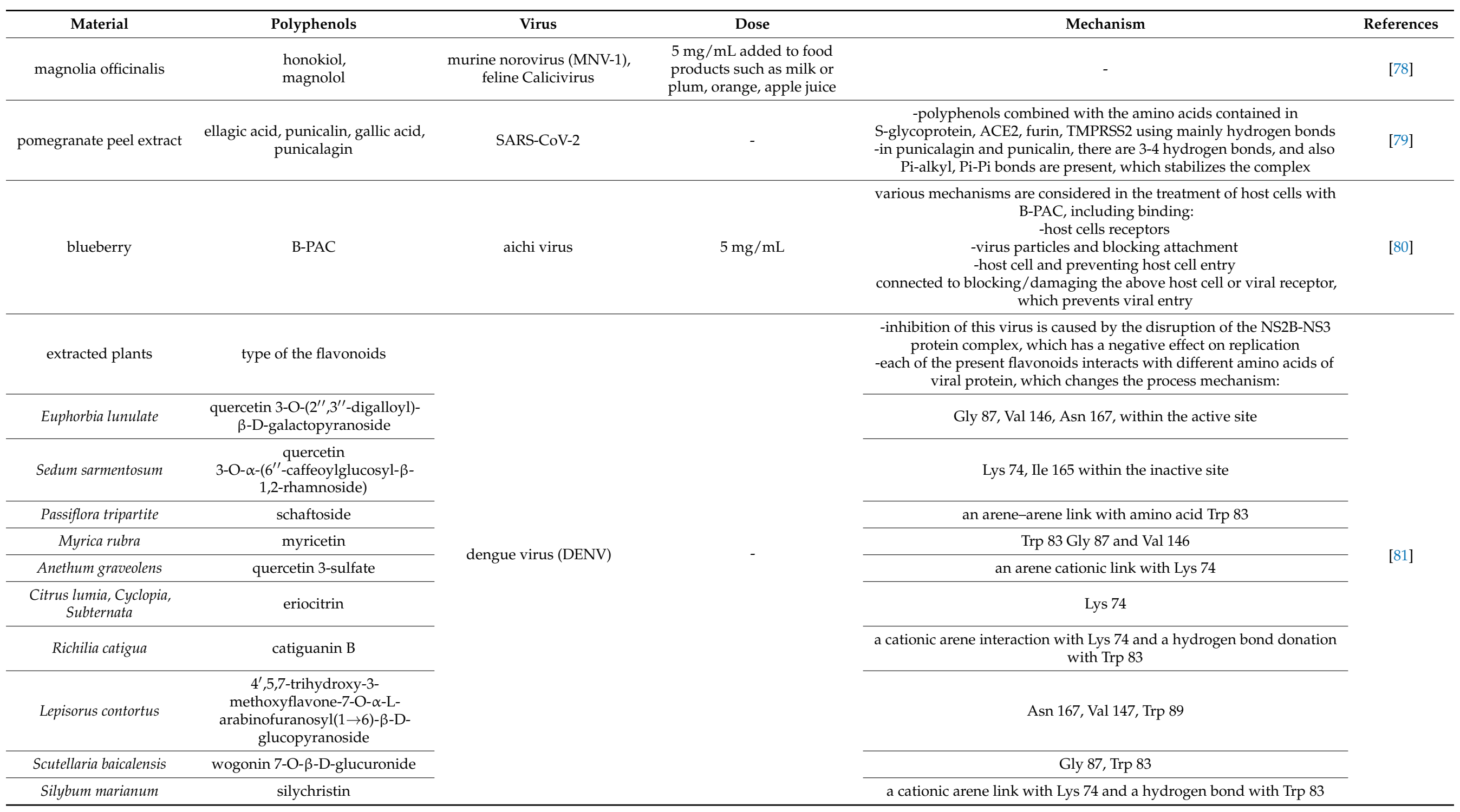


Table 1. Cont

Material

Polyphenols

Virus

\section{Mechanism}

-inhibition is achieved by PB2 that changes

the structure of the $P$ doman of VLPs

the structure of the P domain of VLPs

0.5 and $1 \mathrm{mg} / \mathrm{mL}$ for both compounds, where time was the main factor deciding about

nhibition of the viruses

interactions play a dominant role while PB2 significantly alters tertiary but not secondary structures of VLPs

the mechanism is based on HCV NS3

protease fused with co-factor NS4A, which then binds hesperidin with the catalytic site residues of the NS4A-NS3 protease domain

\begin{tabular}{|c|c|c|c|c|c|}
\hline $\begin{array}{l}\text { grapefruit mesocarp } \\
\text { extract }\end{array}$ & hesperidin & $\mathrm{HCV}$ genotype 3a & IC50-23.32 $\mu \mathrm{mol} / \mathrm{L}$ & $\begin{array}{l}\text { protease fused with co-factor NS4A, which } \\
\text { then binds hesperidin with the catalytic site } \\
\text { residues of the NS4A-NS3 protease domain }\end{array}$ & [83] \\
\hline almond skin extracts & $\begin{array}{c}\text { EC, } \\
\text { eriodictyol } \\
\text { quercetin, } \\
\text { catechin } \\
\text { protocatechuic acid, } \\
\text { kaempferol } \\
\text { p-hydroxybenzoic acid } \\
\text { chlorogenic acid } \\
\text { vanillic acid } \\
\text { isorhamnetin } \\
\text { naringenin } \\
\text { trans-p-coumaric acid } \\
\text { eryodictiol-7-O-glucoside } \\
\text { isorhamnetin-3-O-glucoside } \\
\text { isorhamnetin-3-O-rutinoside } \\
\text { naringenin-7-O-glucoside } \\
\text { kaempferol-3-O-glucoside } \\
\text { kaempferol-3-O-rutinoside } \\
\text { quercetin-3-O-glucoside } \\
\text { quercetin-3-O-galactoside } \\
\text { quercetin-3-O-rutinoside }\end{array}$ & HSV-1 & $\begin{array}{l}0.4 \mathrm{mg} / \mathrm{mL} \text { extracts concentration }(90 \% \\
\text { decrease of viral titer) }\end{array}$ & $\begin{array}{l}\text { NS acts on the HSV- } 1 \text { lytic cycle in that it } \\
\text { blocks virion entry into the cells, i.e., the } \\
\text { polyphenols bind to cell receptors of the } \\
\text { virus, preventing them from entering } \\
\text { the cell }\end{array}$ & [84] \\
\hline
\end{tabular}


Table 1. Cont.

$\begin{array}{cc} & \text { 1. rutamari, } \\ & \text { 2. piperine, } \\ \text { 141 diverse plant and } & \text { 3. piperylin, } \\ \text { fungal species belonging } & \text { 4. 1-[(2E,4E,8E)-9-(1,3- } \\ \text { to } 66 \text { different families, } & \text { benzodioxol-5-yl)-1-oxo-2,4,8- } \\ \text { with asteraceae }(10 \%), & \text { nona-trienyl]-pyrrolidine, } \\ \text { lamiaceae }(10 \%), & \text { 5. piperoleine A, } \\ \text { apiaceae }(6 \%), \text { and } & \text { 6. dehydropipernonaline, } \\ \text { fabaceae }(4 \%) & \text { 7. pipernonaline, } \\ & \text { 8. chabamide, } \\ \text { 9. ganoderol B }\end{array}$

9. ganoderol B
Hong Kong / 68 (HK/68), rhinovirus RV-A2, CV-B3

$$
\text { extracts: }
$$

IC $50-50 \mu \mathrm{g} / \mathrm{mL}(\mathrm{HK} / 68)$

IC50-20 $\mu \mathrm{g} / \mathrm{mL}$ (CV-B3)

IC50-11 $\mu \mathrm{g} / \mathrm{mL}$ (RV-A2)

pure compound:

1. CC50—4.7 $\mu \mathrm{M}$ (MDCK cells) and $4.6 \mu \mathrm{M}$

$$
\text { (HeLa cells), }
$$

2. CC50-50 $\mu \mathrm{M}$ (HeLa cells)

3. CC50 $\geq 100 \mu \mathrm{M}$ (HeLa cells)

4. CC50 $\geq 100 \mu \mathrm{M}$ (HeLa cells)

5. CC50-25 $\mu \mathrm{M}$ (HeLa cells),

6. CC50-34 $\mu \mathrm{M}$ (HeLa cells)

7. CC50-21 $\mathrm{M}$ (HeLa cells),

. CC50-21 $\mu \mathrm{M}$ (HeLa cells)

9. CC50 $\geq 100 \mu \mathrm{M}$ (MDCK cells) and $>100 \mu \mathrm{M}$

1. IC50-2.7 $\mu \mathrm{M}$ (HK/68 in MDCK cells) and 5.1 $\mu \mathrm{M}$ (CV-B3 in HeLa cells),

2. IC50-41 $\mu \mathrm{M}$ (RV-A2 in HeLa cells),

3. IC50-51 $\mu \mathrm{M}$ (CV-B3 in HeLa cells) and 79

$$
\mu \mathrm{M} \text { (RV-A2 in HeLa cells), }
$$

4. IC50-61 $\mu \mathrm{M}$ (CV-B3 in HeLa cells),

5. IC50-22 $\mu \mathrm{M}$ (CV-B3 in HeLa cells),

6. IC50-24 $\mu \mathrm{M}$ (CV-B3 in HeLa cells),

7. IC50-32 $\mathrm{M}$ (CV-B3 in HeLa cells),

8. IC50-9.1 $\mathrm{M}$ (CV-B3 in HeLa cells),

9. IC50-17 $\mu \mathrm{M}$ (HK/68 in MDCK cells) and

65- $\mathrm{MM}$ (RV-A2 in HeLa cells),

IC50—9.19 $\pm 1.99 \mu \mathrm{M}$ A/Puerto Rico/8/34

$$
\text { (H1N1) }
$$

IC50-23.72 $\pm 2.51 \mu \mathrm{M}$ A/Aichi/2/68 (H3N2)

IC50—4.64 $\pm 3.01 \mu \mathrm{M}$ for NA-H274Y (H1N1) isocorilagin inhibiting NA activity in a dose-dependent manner via residues Arg118, Glu119, Arg156, and Glu276. Interaction with NA mainly through hydrogen bonds and van der Waals forces -the inhibition of the influenza virus is accomplished through the suppression of the HA

luteolin-7-glucoside 15\% kaempferol $75 \%$ isoquercetin $5 \%$

CC50-0.90 $\pm 0.01 \mu \mathrm{g} / \mathrm{mL}$ their methanol extract quercetin $2 \%$

MF1 fraction acts at the HA level and thus prevents the virus from binding to the cell surface receptors 
Table 1. Cont.

Material

\section{Polyphenols}

Dose

Mechanism

References

rhamnetin-3-O-b-D-glucuronide-600methyl ester,

rhamnazin-3-O-b-D-glucuronide600-methyl ester,

kaempferol-3-O-b-D-glucuronide-600methyl ester,

isorhamnetin-3-O-b-D-glucuronide600-methyl ester,

rhamnetin-3-O-b-D-glucopyranoside,

$$
\text { quercetin }
$$

3-O-b-D-glucuronide-600-methyl ester quercetin 3-O-b-D-glucuronide quercetin 3-O-b-D-glucuron

flos caryophylli glucopyranoside

hamnazin-3-O-b-D-glucopyranoside

1,2,3-tri-O-galloylglucose,

$$
\text { casuarinin, }
$$

tellimagrandins I,

1,3-Di-O-galloyl-4,6-HHDP-glucose,

$$
\text { casuarictin, }
$$

1,2,3,6-tetra-O-galloylglucose, isobiflori,

$$
\begin{aligned}
& \text { isobiflori, } \\
& \text { biflori }
\end{aligned}
$$

procyanidin $\mathrm{B} 2, \mathrm{O}-\mathrm{h}$ exosides,

Vaccinium oldhamii quercetin-3-O-rhamnosidequercetin-O-

ethanol extracts

pentoside-O

rhamnoside
IC $50-38 \mu \mathrm{g} / \mathrm{mL}(30 \%$ extract $)$

IC $50-22 \mu \mathrm{g} / \mathrm{mL}(40 \%$ extract $)$

IC $50-65 \mu \mathrm{g} / \mathrm{mL}$ ( $50 \%$ extract)

CC $50-251 \mu \mathrm{g} / \mathrm{mL}(30 \%$ extract)

CC50-160 $\mu \mathrm{g} / \mathrm{mL}$ (40\% extract)

CC50-78 $\mu \mathrm{g} / \mathrm{mL}$ (50\% extract) ferulic acid and its derivatives bind NA and inhibit the initial stage of IFV infection,

where quercetin and rhamnoside suppress IFV replication in cells solieria filiformis: kaempferide

solieria filiformis: kaempferide,

3-O-malonylglucoside,

Solieria filiformis, demethoxycentaureidin7-O-rutinoside,

Ecklonia arborea quercetin 3-(6-O-acetyl-beta-glucoside)

ecklonia arborea:
phlorofucofuroeckol-B, formononetin

solieria filiformis:

CC50 $\geq 1500 \mu \mathrm{g} / \mathrm{mL}$

measles virus

C50 $-0.4 \pm 0.11 \mu \mathrm{g} / \mathrm{mL}$

ecklonia arborea:

inhibition of the key surface proteins of the

virus, which is NA, is affected by a group of

polyphenols

apigenin 7-O-glucoside 
Table 1. Cont.

\begin{tabular}{|c|c|c|c|c|c|}
\hline Material & Polyphenols & Virus & Dose & Mechanism & References \\
\hline blueberry & B-PAC & $\begin{array}{l}\text { MNV-1, } \\
\text { FCV-F9 }\end{array}$ & $5 \mathrm{mg} / \mathrm{mL}$ in simulated intestinal fluid & $\begin{array}{l}\text {-in used nutritional models, milk has decreased antiviral } \\
\text { activity because of the presence of complex matrices } \\
\text { containing lipids } \\
\text {-the publication clarifies that the presence of proteolytic } \\
\text { enzymes did not affect the inhibition of those viruses }\end{array}$ & [91] \\
\hline plant based polyphenols & $\begin{array}{c}\text { EGCG, } \\
\text { TF1, } \\
\text { theaflavin -3'-O-gallate (TF2a), } \\
\text { theaflavin-3'-gallate (TF2b), } \\
\text { TF3, } \\
\text { hesperidin, } \\
\text { quercetagetin, } \\
\text { myricetin }\end{array}$ & SARS-CoV-2 & $\begin{array}{c}\text { maximum tolerated dose for } \\
\text { humanEGCG-0.441 (log mg/kg/day) } \\
\text { TF3-0.438 (log } \mathrm{mg} / \mathrm{kg} / \text { day }) \\
\text { TF2b-0.438 (log } \mathrm{mg} / \mathrm{kg} / \text { day }) \\
\text { TF2a-0.439 (log } \mathrm{mg} / \mathrm{kg} / \text { day })\end{array}$ & $\begin{array}{c}\text { the complex is formed by van der Waals bonds, electrostatic } \\
\text { interactions, nonpolar solvation free energy, where } \\
\text { polyphenols bind to the virus through RNA-dependent } \\
\text { RNA polymerase (RdRp) }\end{array}$ & [92] \\
\hline Cassia alata & alatains $\mathrm{A}$ and $\mathrm{B}$ & $\begin{array}{l}\text { tobacco mosaic virus } \\
\text { (TMV) }\end{array}$ & 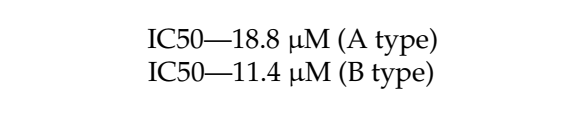 & $\begin{array}{c}\text { the presence of C-14-C-5 linkage between a chromone } \\
\text { moiety and an isocoumarin moiety in the studied } \\
\text { polyphenols }\end{array}$ & [93] \\
\hline eucalyptus bark extract & $\begin{array}{l}\text { benzoic acid, quinol, salicylic } \\
\text { acid, myricetin, rutin }\end{array}$ & TMV & $100 \mu \mathrm{g} / \mathrm{mL}$ & $\begin{array}{l}\text { the direct inhibition of virus replication as well as by } \\
\text { simultaneous activation of the host innate immune response } \\
\text { and inducing SAR against the virus }\end{array}$ & [94] \\
\hline $\begin{array}{l}\text { plants and natural } \\
\text { products based on } \\
\text { polyphenols }\end{array}$ & delphinidin (D), EGCG & $\begin{array}{l}\text { west Nile virus (WNV), } \\
\text { zika virus (ZIKV), DENV }\end{array}$ & $\begin{array}{l}\text { antiviral activity is dose-dependent with } \\
\text { values ranging from } 1-10 \mu \mathrm{M} \text {, the best results } \\
\text { were obtained with } 10 \mu \mathrm{M}\end{array}$ & $\begin{array}{l}\text { inhibition mechanism is based around entry steps of the } \\
\text { virus life cycle, where polyphenols contain } \\
\text { trihydroxyphenyl group at R2, which may interact with the } \\
\text { function of proteins at multiple binding sites }\end{array}$ & [96] \\
\hline $\begin{array}{l}\text { fruits and vegetables } \\
\text { (plant-based } \\
\text { polyphenols) }\end{array}$ & $\begin{array}{l}\text { isoquercitrin } \\
\text { (quercetin-3-O-glucoside or } \\
\text { Q3G) }\end{array}$ & ZIKV & $\begin{array}{c}\text { IC50-15.5 } \pm 2.3 \mu \mathrm{M} \text { (A549), } \\
\text { CC50-551.2 } \pm 43.2 \mu \mathrm{M}(\mathrm{A} 549), \\
\text { IC50-14.0 } \pm 3.8 \mu \mathrm{M} \text { (Huh-7), } \\
\text { CC50-326.8 } \pm 45.7 \mu \mathrm{M} \text { (Huh-7), } \\
\text { IC50-9.7 } \pm 1.2 \mu \mathrm{M} \text { (SH-SY5Y), } \\
\text { CC50-582.2 } \pm 41.4 \mu \mathrm{M} \text { (SH-SY5Y), }\end{array}$ & $\begin{array}{l}\text { polyphenol prevents the internalization of virus particles } \\
\text { into the host cell, most likely by clathrin-mediated } \\
\text { endocytosis pathway involving Axl/Gas6 as entry factors }\end{array}$ & [97] \\
\hline honey, tea, red wine & pinocembrin & ZIKV & IC50-17.4 $\mu \mathrm{M}$ & $\begin{array}{l}\text { polyphenol inhibits the replication cycle of the virus as well } \\
\text { as RNA production and envelope protein synthesis, where } \\
\text { those actions happen in the post-entry stages of the infection }\end{array}$ & [98] \\
\hline
\end{tabular}


Table 2 provides information on the mechanism of action of individual polyphenols, which are plants' main components, showing antiviral properties. Based on the information contained in Table 2, it can be concluded that the mechanism of inhibition for individual polyphenols depends on the type of virus and its structure. Papers regarding the use of resveratrol $[42,52,99]$ indicate the different mechanisms behind the inhibition of the viruses. It has been shown that it affects mainly the virus' replication cycle by interacting with the active sites of caspase or protein synthesis. In the case of curcumin $[60,69,100]$, gallic acid $[101,102]$ and catechin $[103,104]$, examples of an inhibitory effect on the influenza virus are shown. Those publications point out the different methods of inhibition for each compound. For instance, the curcumin action is centered on reducing viral NA activity and blocking HA activity, where catechin tends to merge with functional sites of the virus, which inhibits M2 protein expression and viral synthesis. Gallic acid tends to interact with Arg152 of neuraminidase protein, which affects the replication cycle. Those pieces of information suggest that there is no close correlation between the activity against viruses and highlights the need for further research. Chlorogenic acid [83,105] and EGCG $[25,29,106]$ exhibit mechanisms of action against various types of viruses, which differ significantly from each other; however, for HBV we can display a typical relationship in terms of inhibition of DNA synthesis. This fact presents the possibility of determining the correlation in the prevention of viruses. EGCG mainly suppresses viral growth by inhibiting the replication stage, where chlorogenic acid binds to HepG2.2.15, HepG2.A64. Those facts are the main reason that an unambiguous determination of the inhibition mechanism is difficult and needs further research. The main element that we are able to determine is the stage that a given polyphenol inhibits: stage of infection or virus replication in human cells. However, those pieces of information cannot be used to determine a specific mechanism of suppression for these compounds in the case of other viruses or their behavior in the presence of other polyphenolic or non-polyphenolic compounds. Those dependencies are shown in Table 1, where the compounds listed below occur and the inhibition mechanisms described are significantly different. This indicates the need for detailed studies, which must be carried out on each individual virus in order to determine the mechanism behind the antiviral activity. Research should be conducted by testing a wider variety of viruses for each polyphenol and then carrying out comprehensive studies of synergic reactions between other compounds in, e.g., plant extracts that change the nature of the virus inhibition mechanics or increase the efficiency of this process. 
Table 2. Antiviral activity mechanism of individual polyphenols mostly found in plants

\begin{tabular}{|c|c|c|c|}
\hline Polyphenol & Virus Type & Activity Mechanism & Refs. \\
\hline quercetin & SARS-CoV-2 & $\begin{array}{l}\text { interaction with Spike occurs between amino acid Thr 445, Ile 446; as for main protease it binds to Thr } 26 \\
\text { superior main protease docking result compared to spike docking, better inhibitory effect on replication } \\
\text { cycle of the virus rather than penetration/adsorption cycle }\end{array}$ & [16] \\
\hline \multirow{2}{*}{ resveratrol } & rotavirus & inhibition of the replication in the Caco-2 cell line & [52] \\
\hline & vesicular stomatitis virus & suppression of the spread of the virus by interaction with the active sites of caspase- 3 and -7 & [99] \\
\hline \multirow{3}{*}{ curcumin } & SARS-CoV-2 & $\begin{array}{l}\text { entry into host cells is also blocked by blocking the enzyme ACE2; curcumin has a high affinity for } \\
\text { ACE2 ligands }\end{array}$ & {$[60]$} \\
\hline & influenza virus & reduction of viral NA activity and blocking HA activity & [69] \\
\hline & SARS-CoV-2 & $\begin{array}{l}\text { inhibition due to interaction with Mpro receptor of SARS-CoV-2, which occurs by binding with amino } \\
\text { acid Thr26, His41, Gln189 }\end{array}$ & [100] \\
\hline \multirow{2}{*}{ EGCG } & $\mathrm{HCV}$ & suppressing by blocking virus entry via viral envelope proteins and inhibiting cell-to-cell transmission & [25] \\
\hline & HBV & inhibition of DNA synthesis during virus replication & [29] \\
\hline \multirow[t]{2}{*}{ chlorogenic acid } & infectious bursal disease virus & $\begin{array}{l}\text { inhibiting histamine production, NF-kB activation, which affects the production of the } \\
\text { pro-inflammatory cytokines TNF-a and IL-1b }\end{array}$ & [105] \\
\hline & HBV & inhibiting DNA of the virus by binding to HepG2.2.15 and HepG2.A64 & [107] \\
\hline \multirow[t]{2}{*}{ catechin } & influenza A virus & $\begin{array}{l}\text { binding to functional sites PHE47A and LEU43A, which inhibits M2 viral mRNA synthesis as well as } \\
\text { M2 protein expression }\end{array}$ & [103] \\
\hline & dengue virus & interaction with NS5 protein, by binding to amino acids Asn609, Asp663, His798 & [104] \\
\hline \multirow{2}{*}{ gallic acid } & influenza A virus & inhibition of replication of the virus, by binding to Arg152 of neuraminidase protein & [101] \\
\hline & paramyxoviruses & affects replication cycle of the virus by inhibiting ribonucleotide reductase enzyme & [102] \\
\hline
\end{tabular}




\section{Clinical Trials}

Reviewing the available literature on the antiviral activity of polyphenols, it can be noted that clinical trials evaluating their efficacy are an integral part of the development of new preparations. In most papers, the authors mainly focus on studies conducted on isolated cells from animal [1] or human organisms [2], but there are also many reports confirming the efficacy of polyphenols in human studies [3].

A study on 92 patients with HIV / AIDS was designed to indicate the relationship of the amount of polyphenol intake on the lipid profiles of infected subjects. The participants were given dark chocolate containing $2148 \mathrm{mg}$ of polyphenols and $3 \mathrm{~g}$ of mate tea, which contained $107 \mathrm{~g}$ of polyphenols. Consumption of the products for 15 days significantly improved the concentration of lipoprotein cholesterol. This is essential for the cardiovascular protection of patients but does not directly indicate the effect of polyphenols on antiviral activity [4]. Dactavira drug administered in tablet form has also been confirmed to treat $\mathrm{HCV}$ in clinical trials. The formulation composed of sofosbuvir, daclatisvir and epigallocatechin gallate was tested against standard therapy (sofosbuvir and daclatisvir). The treatment resulted in a significant decrease in viral load compared to the conventionally treated group. Incorporation of epigallocatechin gallate resulted in disruption of viral entry, which substantially prevents relapse [5].

Many experiments conducted on cells have shown that green tea catechins have health-promoting effects within the reproductive organs [6]. A 12-week-long study showed that an ointment containing green tea polyphenols (Polyphenon E) was effective in treating external genital warts. A positive treatment effect was found in both men and women. Only about $8 \%$ of patients experienced mild adverse events [7]. Another study showed that as many as $53 \%$ of patients treated with Polyphenon E $15 \%$ were completely cured of primary and new anal and genital warts (about $60 \%$ of women and $45 \%$ of men), while adverse effects occurred only at the application site [8]. Approximately $60 \%$ complete removal of warts, with $10 \%$ recurrence of the disease, was found using $10 \%$ and $15 \%$ sinecatechin-containing ointment. In studies, up to $50 \%$ of patients showed local mild to moderate adverse reactions [9]. The clinical efficacy of green tea extracts (Polyphenon E; poly $\mathrm{E}$ and (-)-epigallocatechin-3-gallate) administered as ointments or capsules to patients infected with human papillomavirus was investigated. It was indicated that as many as $69 \%$ of those treated showed a response. The collected data indicated the possibility of treating cervical lesions caused by human papillomavirus with green tea extracts [10].

Clinical trials also support the effectiveness of polyphenols as adjuvants during antibiotic therapy. The effect of resveratrol in synergy with amoxicillin on improving the treatment of children with pneumonia was investigated. The treatment failure rate was significantly lower on day 3 than patients who received a placebo [11]. Resveratrol was also studied in combination with the carboxymethyl- $\beta$-glucan solution or saline solution. Intranasal application to patients with upper respiratory tract infection (rhinovirus) reduced symptoms compared to the control group [12].

Many preclinical studies also suggest that polyphenols (including quercetin) also have immunomodulatory and antimicrobial effects. However, these are mostly studies with a low coefficient of statistical significance [13]. According to one study, consumption of quercetin does not affect immune function, but reduces the incidence of upper respiratory infections after intense exercise [14]. Other information was provided in another paper where a study was conducted on approximately 1002 patients. The study did not confirm significant differences between those taking quercetin and patients treated with a placebo [15].

The in vitro evaluation of individual polyphenols is an essential step in studying the effect of compounds on antiviral activity. Although research on selected polyphenols is already advanced, detailed information on the impact of most compounds on their antiviral activity confirmed in clinical trials is still lacking. Current evidence for the efficacy of polyphenol supplementation in treatment is promising but mostly insufficient. 


\section{Methods of Polyphenol Isolation}

The isolation of polyphenols in the initial stage is determined by the type (extractable or non-extractable) and their future application. Green isolation methods are applied for plant extracts. Therefore, extraction (of varying complexity and advancement) and hydrolysis of plant material (acid or enzymatic, especially for non-extractable polyphenols) are most commonly implemented. A summary of polyphenol isolation and determination methods is described in Table 3.

The first step in the isolation of polyphenols is the sample preparation. In addition to grinding the plant to pieces/particles of appropriate size, it is often necessary to remove compounds that could be coextracted, but their presence is not desired. This mainly concerns lipophilic compounds removed by organic solvents such as a mixture of petroleum ether and ethyl acetate [108], dichloromethane [109] or n-hexane [110]. With ethyl acetate, it is also possible to remove extractable polyphenols when isolation of non-extractable polyphenols is expected [111].

A review of the literature indicates that classical solvent extraction is most commonly applied. This process is performed with water, organic solvents (ethanol, acetone, methanol, formic acid) or mixtures in different volume ratios. Extraction can be carried out over a wide range of time, from $10 \mathrm{~min}$ to $24 \mathrm{~h}[112,113]$. A major limitation of the process with organic solvents (especially toxic ones, such as acetone or methanol) is the necessity to remove the extractant before the extracts can be used for pharmaceutical purposes. Vacuum distillation under reduced pressure is most frequently implemented [114]. This solution ensures effective purification of the extract and the process conditions $(\mathrm{p}, \mathrm{T})$ do not cause polyphenol degradation. However, an additional unit process increases production time and cost [115]. A special case of classical extraction is the maceration of plant material, which is carried out at ambient temperature. This process does not require an elevated temperature that could affect the polyphenol isolation efficiency, so it is increased by an appropriately selected solvent [114].

An advanced technique that belongs to the group of green methods is supercritical fluid extraction. On the industrial scale, carbon dioxide, water, ethanol or their mixtures are used. Under appropriate pressure/temperature conditions (higher than critical values) $\mathrm{CO}_{2}$ is put into a supercritical state, obtaining liquid and gas properties simultaneously. It is considered that this method is suitable for materials containing thermosensitive polyphenols [116]. The added value of SFE is the high purity of the extracts, which are free of extractants because as the system $(\mathrm{p}, \mathrm{T})$ is returned to ambient conditions, the extractants (mainly $\mathrm{CO}_{2}$ ) separate from the extract spontaneously. This method is highly efficient and the residence time of one batch is short. However, special equipment and infrastructure and a large financial investment (adequate pressure is costly) are needed to produce supercritical fluids [117]. 
Table 3. Methods of polyphenol isolation and determination.

\begin{tabular}{|c|c|c|c|c|c|}
\hline Material & Pretreatment & Polyphenol Isolation & Time & Polyphenol Determination & References \\
\hline soursop leaves & - & water and ethanol/water $(70: 30 \mathrm{v} / \mathrm{v})$ extraction & $10-20 \mathrm{~min}$ & HPLC & [112] \\
\hline olive waste & - & ultrasound-assisted enzyme catalyzed hydrolysis & - & 1H NMR and 13C NMR & [118] \\
\hline Heliotropium taltalense & & methanol extraction in an ultrasonic bath & $1 \mathrm{~h}$ & UPLC & [119] \\
\hline maritime pine & $\begin{array}{l}\text { removing lipophilic compunds } \\
\text { with a petroleum ether/ethyl } \\
\text { acetate }(50: 50 \mathrm{v} / \mathrm{v}) \text { mixture }\end{array}$ & ethanol/water $(85: 15 v / v)$ extraction & $2 \mathrm{~h}$ & LC-MS and NMR & [108] \\
\hline Cuspidaria convoluta & - & methanol maceration & $24 \mathrm{~h}$ & UV-VIS and HPLC-MS/MS & [114] \\
\hline green tea & - & ethanol/water $(70: 10, v / v)$ extraction in ultrasonic cleaner & $1 \mathrm{~h}$ & HPLC and LC-MS & [121] \\
\hline Aronia melanocarpa & $\begin{array}{l}\text { defatting with n-hexane and with } \\
\text { dichloromethane }\end{array}$ & methanol/acetic acid $(19: 1, v / v)$ extraction with stirring & $8 \mathrm{~h}$ & HPLC & [110] \\
\hline Saharan myrtle tea & - & methanol/water $(80: 20, v / v)$ extraction & $3 \cdot 24 \mathrm{~h}$ & UPLC & [113] \\
\hline Syzygium alternifolium & $\begin{array}{l}\text { removing lipophilic compunds } \\
\text { with a dichloromethane }\end{array}$ & $\begin{array}{l}\text { methanol/water }(80: 20, v / v) \text { or acetone/water }(80: 20 v / v) \\
\text { extraction with sonification }\end{array}$ & $15 \mathrm{~min}$ & UV-VIS & [109] \\
\hline pomegranate peels & $\begin{array}{l}\text { removing of extractable } \\
\text { polyphenols using ethyl acetate }\end{array}$ & $\begin{array}{l}\text { non-extractable polyphenols obtained via acid hydrolysis } \\
\qquad(6 \mathrm{M} \mathrm{HCl})\end{array}$ & $2 \mathrm{~h}$ & TLC, CC, NMR, MALDI-TOF-MS & [111] \\
\hline grape processing lees & - & $\begin{array}{l}\text { supercritical fluid extraction (SFE) with } 90 \% \text { of } \\
\text { supercritical carbon dioxide and } 10 \%(w / w) \text { of ethanol }\end{array}$ & $10 \mathrm{~min}$ & TLC and HPLC & [116] \\
\hline Myrtus communis $L$. leaves & - & $\begin{array}{l}\text { extraction with aqueous ethanol with assistance of } \\
\text { microwaves }\end{array}$ & $30-90 \mathrm{~s}$ & $\begin{array}{l}\text { Folin-Ciocalteu colorimetric } \\
\text { method }\end{array}$ & [122] \\
\hline goldenberry & - & $\begin{array}{c}\text { ethanol/water solution }(70: 30, v / v) \text { pressurized liquid } \\
\text { extraction (PLE) }\end{array}$ & $10-60 \mathrm{~min}$ & HPLC-DAD & [123] \\
\hline grape pomace & - & pressurized hot water extraction (PHWE) & 5 or $30 \mathrm{~min}$ & MALDI-TOF-MS & [124] \\
\hline Phyllanthus Emblica & - & soxlet extraction with ethanol/water $(7: 3, v / v)$ & $30 \mathrm{~min}$ & $\begin{array}{l}\text { Folin-Ciocalteu colorimetric } \\
\text { method }\end{array}$ & [125] \\
\hline
\end{tabular}

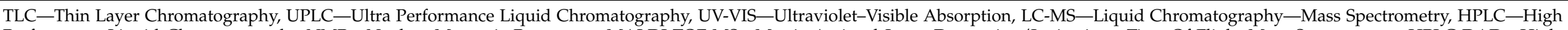

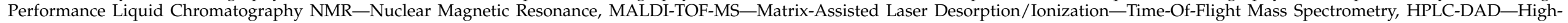

Performance Liquid Chromatography_-Diode-Array Detection. 
Increasing the efficiency of conventional extraction is carried out with the assistance of ultrasound or microwaves. It is assumed that these enhancement methods affect the breakdown of plant cells, which facilitates the leaching of bioactive compounds from the plant matrix. Although these methods provide higher yields and significantly reduce extraction time, they must be well optimized before a large-scale implementation [108,122]. The application of ultrasounds can lead to the formation of reactive oxygen species and free radicals, causing the breakdown of polyphenols. Elevated temperatures also cause this phenomenon. On the other hand, in the technique utilizing microwaves, an increase in temperature is observed during the process, and therefore the power of the microwaves must be experimentally selected in relation to the extracted material and the extractant used [117].

Green extraction methods include pressurized liquid extraction (PLE) and pressurized hot water extraction (PHWE). Increasing pressure and therefore increasing temperature leads to a decrease in the viscosity of the extractant, which affects the polyphenol leaching efficiency $[123,124]$. These methods do not require complicated instrumentation, thus the cost of the process is low. This cost is reduced, especially in PHWE, where the extractant is water, making this method the most ecologically friendly [117]. The reduction of organic solvents eliminates the need to purify extracts (before medical use) and facilitates separation and analytical procedures [124]. However, it should be noted that the choice of temperature (above the boiling point, but below the critical point) requires optimization with respect to the extracted polyphenols from specific biomass. Too high a temperature can lead to the degradation of polyphenols [117].

Literature data also describe the utilization of acid or enzyme-induced hydrolysis. These methods are applicable to problematic materials, such as olive waste or to isolate non-extractable polyphenols. These cases are dedicated to difficult matrices that contain a large amount of secondary compounds (e.g., fats) or are required by the structure of the material [111,118].

The literature also describes the potential of using a new generation of green solvents, called natural deep eutectic solvents (NADES). These are mixtures of basic plant metabolites, such as sugars, amino acids, alcohols, organic acids, amines or choline derivatives, which exhibit the properties of ionic liquid and deep eutectic solvents [126]. The potential of NADES in polyphenol extraction is due to their unique properties-viscosity, polarity, and formation of hydrogen bonds with polyphenols [127].

It is estimated that, compared to classical methods, extraction with NADES results in higher yields. This has been proven in the extrusion of Carthamus tinctorius L. with various eutectic solvents, including lactic acid-glucose, proline-malic acid and sucrose-choline chloride [128]. In another study, NADES were used to extract the alga Chlorella vulgaris to obtain an extract rich in antioxidants (including the polyphenols gallic acid, caffeic acid, p-coumaric acid and ferulic acid). In addition to higher yields, extraction with NADES was also found to result in increased antioxidant activity of the extracts and selectivity of target antioxidants. Thus, this method allows a more efficient recovery of valuable bioactive compounds from biomass without exposing them to degradation or inactivation [129].

The efficiency of polyphenol isolation methods is evaluated by various instrumental analysis techniques via spectrophotometry, mass spectrometry, chromatography or magnetic resonance. In the simplest way, TPC is determined colorimetrically with the Folin-Ciocalteu reagent. This technique uses a color reaction between the polyphenols and the reagent applied, resulting in blue color. The concentration of polyphenols is determined by measuring the absorbance at a wavelength of $750 \mathrm{~nm}$ [122]. More advanced systems use chromatography, which both separates the mixture and examines its composition. In the determination of polyphenols, basic thin layer chromatography (TLC) [116], high performance and ultra-performance liquid chromatography (HPLC and UPLC) [113], as well as liquid chromatographs equipped with a mass detector (LC-MS), are used [121]. More advanced methods such as nuclear magnetic resonance NMR or MALDI-TOF-MS are 
also applicable [111]. For detection of polyphenols, ultraviolet-visible absorption (UV-vis) is widely used. Advanced techniques allow the determination of the total concentration of polyphenols in plant extracts and the identification of individual compounds.

\section{Conclusions and Future Perspectives}

The bioactive compounds in plants and their extracts have antiviral activity and can be used preventively or to fight infections. There are still plant varieties (some exotic) or their edible parts where the polyphenol profiles are not yet identified. Available detection (UV-Vis, NMR, TLC, HPLC, UPLC, LC-MS) and isolation (extraction, hydrolysis) methods are sufficient for these compounds' quantitative and qualitative determination.

Recent studies have been centered on examining which components of polyphenolic extracts inhibit viruses of various origins, along with the determination of the inhibitory doses. Preliminary research indicates possible inhibitory mechanisms that are mainly connected to the early stages of infection. The most frequently indicated effects of polyphenols on viruses are the viral replication cycle, reduction in gene expression, changes in the structure of the virus, interaction through RNA-dependent RNA polymerase, etc. Those interactions depend on the virus' origin, the type of polyphenol compounds used, and their synergistic interactions. An important topic that has been discussed in recent publications is the synergistic interaction of two or more polyphenols, which can improve the inhibiting effect, even if they have little or no antiviral activity separately. The unambiguous identification of the inhibitory mechanism of those compounds is the main issue for which comprehensive studies should be carried out to determine the relationship between given groups of substances and their effect on viruses.

An innovative approach is the synthesis of polyphenols based on the use of components of natural origin and the combination of synthetic and natural components. The use of such treatments increases the bioavailability of the ingredients, thus increasing the preparations' effectiveness. Currently, in vitro and in vivo studies have been mostly limited to cellular or single organism tests. There is no confirmation of the effectiveness of polyphenols in clinical trials. Such efforts would also allow a better evaluation of their absorption, metabolism and excretion in the human body and exclude side effects, about which little is known.

Author Contributions: Conceptualization, K.C. and A.W.-K.; methodology, A.W.-K.; writingoriginal draft preparation, G.I., D.S. (Dawid Skrzypczak), K.M. and D.S. (Daniel Szopa); writingreview and editing K.C. and A.W.-K.; supervision, K.C. All authors have read and agreed to the published version of the manuscript.

Funding: The research was co-financed by the statutory activity subsidy in 2021 from the Polish Ministry of Science and Higher Education for the Faculty of Chemistry of Wrocław University of Science and Technology: Department of Advanced Material Technologies-No 8211104160/K26W03D05.

Institutional Review Board Statement: Not applicable.

Conflicts of Interest: The authors declare no conflict of interest.

$\begin{array}{ll}\text { Abbreviations } & \\ \text { B-PAC } & \begin{array}{l}\text { B-type proanthocyanidins } \\ \text { coxsackie virus type B-3 } \\ \text { CV-B3 }\end{array} \\ \text { CC } & \text { dengue virus } \\ \text { DENV } & \text { duck Tembusu virus } \\ \text { DTMUV } & \text { effective concentration } \\ \text { EC } & \text { epicatechin gallate } \\ \text { ECG } & \text { epigallocatechin-3-gallate } \\ \text { EGCG } & \text { felinecalici virus } \\ \text { FCV } & \text { hemagglutinins } \\ \text { HA } & \end{array}$




\begin{tabular}{|c|c|}
\hline HAV & hepatitis A virus \\
\hline HBV & hepatitis B virus \\
\hline $\mathrm{HCV}$ & hepatitis $C$ virus \\
\hline HPLC & high performance liquid chromatography \\
\hline HPLC-DAD & high performance liquid chromatography-diode-array detection \\
\hline HSV-1 & herpes simplex virus 1 \\
\hline HSV-2 & herpes simplex virus 2 \\
\hline IAV & influenza virus A type \\
\hline IC & inhibitory concentration \\
\hline IBV & influenza virus B type \\
\hline ID & infective dose \\
\hline LC-MS & liquid chromatographs equipped with a mass detector \\
\hline MALDI-TOF-MS & matrix-assisted laser desorption/ionization-time-of-flight mass spectrometry \\
\hline MNV-1 & murine norovirus \\
\hline MPXV & monkeypox virus \\
\hline NA & neuraminidase \\
\hline NADES & natural deep eutectic solvents \\
\hline NMR & Nuclear Magnetic Resonance \\
\hline PA2 & proanthocyanidin A2 \\
\hline PAC-A & A-type proanthocyanidins \\
\hline PHWE & pressurized hot water extraction \\
\hline PLE & pressurized liquid extraction \\
\hline PRRS & porcine reproductive and respiratory syndrome \\
\hline RV & rhinovirus \\
\hline SARS & severe acute respiratory syndrome \\
\hline TF1 & theaflavin \\
\hline TF2 & theaflavin- $3^{\prime}$-monogallate \\
\hline TF2a & theaflavin-3'-O-gallate \\
\hline TF2b & theaflavin- $3^{\prime}$-gallate \\
\hline TF3 & theaflavin-3-3'-digallate \\
\hline TLC & thin layer chromatograph \\
\hline TMV & tobacco mosaic virus \\
\hline TPC & total phenolic content \\
\hline UPLC & ultra performance liquid chromatography \\
\hline UV-VIS & Ultraviolet-visible absorption \\
\hline VACV & vaccinia virus \\
\hline ZIKV & zika virus \\
\hline
\end{tabular}

\section{References}

1. Veeresham, C. Natural products derived from plants as a source of drugs. J. Adv. Pharm. Technol. Res. 2012, 3, 200-201. [CrossRef] [PubMed]

2. Karimi, A.; Majlesi, M.; Rafieian-Kopaei, M. Herbal versus synthetic drugs; beliefs and facts. J. Nephropharmacology $2015,4,27$.

3. Giovinazzo, G.; Gerardi, C.; Uberti-Foppa, C.; Lopalco, L. Can natural polyphenols help in reducing cytokine storm in COVID-19 patients? Molecules 2020, 25, 5888. [CrossRef] [PubMed]

4. Pérez-Jiménez, J.; Neveu, V.; Vos, F.; Scalbert, A. Identification of the 100 richest dietary sources of polyphenols: An application of the Phenol-Explorer database. Eur. J. Clin. Nutr. 2010, 64, 112-120. [CrossRef] [PubMed]

5. Manach, C.; Scalbert, A.; Morand, C.; Rémésy, C.; Jiménez, L. Polyphenols: Food sources and bioavailability. Am. J. Clin. Nutr. 2004, 79, 727-747. [CrossRef] [PubMed]

6. Chowdhury, P.; Barooah, A.K. Tea Bioactive Modulate Innate Immunity: In Perception to COVID-19 Pandemic. Front. Immunol. 2020, 11, 1-9. [CrossRef]

7. Besednova, N.N.; Andryukov, B.G.; Zaporozhets, T.S.; Kryzhanovsky, S.P.; Fedyanina, L.N.; Kuznetsova, T.A.; Zvyagintseva, T.N.; Shchelkanov, M.Y. Antiviral effects of polyphenols from marine algae. Biomedicines 2021, 9, 200. [CrossRef]

8. Song, L.-G.; Xie, Q.-X.; Lao, H.-L.; Lv, Z.-Y. Human coronaviruses and therapeutic drug discovery. Infect. Dis. Poverty 2021, 10, 1-21. [CrossRef]

9. Chojnacka, K.; Witek-Krowiak, A.; Skrzypczak, D.; Mikula, K.; Młynarz, P. Phytochemicals containing biologically active polyphenols as an effective agent against Covid-19-inducing coronavirus. J. Funct. Foods 2020, 73, 104146. [CrossRef]

10. Ahmad, S.; Zahiruddin, S.; Parveen, B.; Basist, P.; Parveen, A.; Parveen, R.; Ahmad, M. Indian Medicinal Plants and Formulations and Their Potential Against COVID-19-Preclinical and Clinical Research. Front. Pharmacol. 2021, 11, 2470. [CrossRef] 
11. Kim, H.; Chung, M.S. Antiviral activities of mulberry (Morus alba) juice and seed against influenza viruses. Evid. Based Complement. Altern. Med. 2018, 2018, 2606583. [CrossRef] [PubMed]

12. Park, S.; Kim, J., II; Lee, I.; Lee, S.; Hwang, M.W.; Bae, J.Y.; Heo, J.; Kim, D.; Han, S.Z.; Park, M.S. Aronia melanocarpa and its components demonstrate antiviral activity against influenza viruses. Biochem. Biophys. Res. Commun. 2013, 440, 14-19. [CrossRef] [PubMed]

13. Ulomskiy, E.N.; Ivanova, A.V.; Gorbunov, E.B.; Esaulkova, I.L.; Slita, A.V.; Sinegubova, E.O.; Voinkov, E.K.; Drokin, R.A.; Butorin, I.I.; Gazizullina, E.R.; et al. Synthesis and biological evaluation of 6-nitro-1,2,4-triazoloazines containing polyphenol fragments possessing antioxidant and antiviral activity. Bioorganic Med. Chem. Lett. 2020, 30, 127216. [CrossRef]

14. Sgarbanti, R.; Amatore, D.; Celestino, I.; Marcocci, M.; Fraternale, A.; Ciriolo, M.; Magnani, M.; Saladino, R.; Garaci, E.; Palamara, A.; et al. Intracellular Redox State as Target for Anti-Influenza Therapy: Are Antioxidants Always Effective? Curr. Top. Med. Chem. 2014, 14, 2529-2541. [CrossRef]

15. Gramza-Michałowska, A.; Sidor, A.; Kulczyński, B. Berries as a potential anti-influenza factor-A review. J. Funct. Foods 2017, 37, 116-137. [CrossRef]

16. Zakay-Rones, Z.; Thom, E.; Wollan, T.; Wadstein, J. Randomized study of the efficacy and safety of oral elderberry extract in the treatment of influenza A and B virus infections. J. Int. Med. Res. 2004, 32, 132-140. [CrossRef]

17. Ikuta, K.; Hashimoto, K.; Kaneko, H.; Mori, S.; Ohashi, K.; Suzutani, T. Anti-viral and anti-bacterial activities of an extract of blackcurrants (Ribes nigrum L.). Microbiol. Immunol. 2012, 56, 805-809. [CrossRef]

18. Sekizawa, H.; Ikuta, K.; Mizuta, K.; Takechi, S.; Suzutani, T. Relationship between polyphenol content and anti-influenza viral effects of berries. J. Sci. Food Agric. 2013, 93, 2239-2241. [CrossRef]

19. Ryu, Y.B.; Jeong, H.J.; Yoon, S.Y.; Park, J.Y.; Kim, Y.M.; Park, S.J.; Rho, M.C.; Kim, S.J.; Lee, W.S. Influenza virus neuraminidase inhibitory activity of phlorotannins from the edible brown alga ecklonia cava. J. Agric. Food Chem. 2011, 59, 6467-6473. [CrossRef] [PubMed]

20. Derksen, A.; Kühn, J.; Hafezi, W.; Sendker, J.; Ehrhardt, C.; Ludwig, S.; Hensel, A. Antiviral activity of hydroalcoholic extract from Eupatorium perfoliatum L. Against the attachment of influenza A virus. J. Ethnopharmacol. 2016, 188, 144-152. [CrossRef] [PubMed]

21. Sundararajan, A.; Ganapathy, R.; Huan, L.; Dunlap, J.R.; Webby, R.J.; Kotwal, G.J.; Sangster, M.Y. Influenza virus variation in susceptibility to inactivation by pomegranate polyphenols is determined by envelope glycoproteins. Antiviral Res. 2010, 88, 1-9. [CrossRef] [PubMed]

22. $\mathrm{Wu}, \mathrm{Y} . \mathrm{H}$. Naturally derived anti-hepatitis B virus agents and their mechanism of action. World J. Gastroenterol. 2016, 22, 188-204. [CrossRef] [PubMed]

23. Cheng, Z.; Sun, G.; Guo, W.; Huang, Y.; Sun, W.; Zhao, F.; Hu, K. Inhibition of hepatitis B virus replication by quercetin in human hepatoma cell lines. Virol. Sin. 2015, 30, 261. [CrossRef]

24. Parvez, M.K.; Tabish Rehman, M.; Alam, P.; Al-Dosari, M.S.; Alqasoumi, S.I.; Alajmi, M.F. Plant-derived antiviral drugs as novel hepatitis B virus inhibitors: Cell culture and molecular docking study. Saudi Pharm. J. 2019, 27, 389-400. [CrossRef]

25. Ciesek, S.; von Hahn, T.; Colpitts, C.C.; Schang, L.M.; Friesland, M.; Steinmann, J.; Manns, M.P.; Ott, M.; Wedemeyer, H.; Meuleman, P.; et al. The green tea polyphenol, epigallocatechin-3-gallate, inhibits hepatitis C virus entry. Hepatology 2011, 54, 1947-1955. [CrossRef]

26. Calland, N.; Albecka, A.; Belouzard, S.; Wychowski, C.; Duverlie, G.; Descamps, V.; Hober, D.; Dubuisson, J.; Rouillé, Y.; Séron, K. (-)-Epigallocatechin-3-gallate is a new inhibitor of hepatitis C virus entry. Hepatology 2012, 55, 720-729. [CrossRef]

27. Chowdhury, P.; Sahuc, M.E.; Rouillé, Y.; Rivière, C.; Bonneau, N.; Vandeputte, A.; Brodin, P.; Goswami, M.; Bandyopadhyay, T.; Dubuisson, J.; et al. Theaflavins, polyphenols of black tea, inhibit entry of hepatitis C virus in cell culture. PLoS ONE 2018, 13, e0198226. [CrossRef]

28. Liu, S.; Chen, R.; Hagedorn, C.H. Tannic acid inhibits hepatitis C virus entry into Huh7.5 cells. PLoS ONE 2015, 10, e0131358. [CrossRef] [PubMed]

29. He, W.; Li, L.X.; Liao, Q.J.; Liu, C.L.; Chen, X.L. Epigallocatechin gallate inhibits HBV DNA synthesis in a viral replicationinducible cell line. World J. Gastroenterol. 2011, 17, 1507-1514. [CrossRef] [PubMed]

30. Pang, J.Y.; Zhao, K.J.; Wang, J.B.; Ma, Z.J.; Xiao, X.H. Green tea polyphenol, epigallocatechin-3-gallate, possesses the antiviral activity necessary to fight against the hepatitis B virus replication in vitro. J. Zhejiang Univ. Sci. B 2014, 15, 533-539. [CrossRef] [PubMed]

31. Nakamura, M.; Saito, H.; Ikeda, M.; Hokari, R.; Kato, N.; Hibi, T.; Miura, S. An antioxidant resveratrol significantly enhanced replication of hepatitis C virus. World J. Gastroenterol. 2010, 16, 184-192. [CrossRef] [PubMed]

32. Shi, Y.; Li, Y.; Huang, C.; Ying, L.; Xue, J.; Wu, H.; Chen, Z.; Yang, Z. Resveratrol enhances HBV replication through activating Sirt1-PGC-1 $\alpha$-PPAR $\alpha$ pathway. Sci. Rep. 2016, 6, 1-12. [CrossRef] [PubMed]

33. Lee, S.; Mailar, K.; Kim, M.I.; Park, M.; Kim, J.; Min, D.H.; Heo, T.-H.; Bae, S.K.; Choi, W.; Lee, C. Plant-Derived Purification, Chemical Synthesis, and In Vitro/In Vivo Evaluation of a Resveratrol Dimer, Viniferin, as an HCV Replication Inhibitor. Viruses 2019, 11, 890. [CrossRef] [PubMed]

34. Hesari, A.; Ghasemi, F.; Salarinia, R.; Biglari, H.; Hassan, A.T.M.; Abdoli, V.; Mirzaei, H. Effects of curcumin on NF-кB, AP-1, and Wnt/ $\beta$-catenin signaling pathway in hepatitis B virus infection. J. Cell. Biochem. 2018, 119, 7898-7904. [CrossRef] 
35. Wei, Z.-Q.; Zhang, Y.-H.; Ke, C.-Z.; Chen, H.-X.; Ren, P.; He, Y.-L.; Hu, P.; Ma, D.-Q.; Luo, J.; Meng, Z.-J. Curcumin inhibits hepatitis B virus infection by down-regulating cccDNA-bound histone acetylation. World J. Gastroenterol. 2017, 23, $6252-6260$. [CrossRef]

36. Denaro, M.; Smeriglio, A.; Barreca, D.; De Francesco, C.; Occhiuto, C.; Milano, G.; Trombetta, D. Antiviral activity of plants and their isolated bioactive compounds: An update. Phyther. Res. 2020, 34, 742-768. [CrossRef]

37. Torky, Z.A.; Hossain, M.M. Pharmacological evaluation of the Hibiscus herbal extract against Herpes Simplex Virus-type 1 as an antiviral drug in vitro. Int. J. Virol. 2017, 13, 68-79. [CrossRef]

38. Wu, C.Y.; Yu, Z.Y.; Chen, Y.C.; Hung, S.L. Effects of epigallocatechin-3-gallate and acyclovir on herpes simplex virus type 1 infection in oral epithelial cells. J. Formos. Med. Assoc. 2021. Available online: https://www.sciencedirect.com/science/article/ pii/S0929664620306185 (accessed on 6 June 2021). [CrossRef]

39. Musarra-Pizzo, M.; Pennisi, R.; Ben-Amor, I.; Smeriglio, A.; Mandalari, G.; Sciortino, M.T. In vitro anti-HSV-1 activity of polyphenol-rich extracts and pure polyphenol compounds derived from pistachios kernels (Pistacia vera L.). Plants 2020, 9, 267. [CrossRef]

40. El-Toumy, S.A.; Salib, J.Y.; El-Kashak, W.A.; Marty, C.; Bedoux, G.; Bourgougnon, N. Antiviral effect of polyphenol rich plant extracts on herpes simplex virus type 1. Food Sci. Hum. Wellness 2018, 7, 91-101. [CrossRef]

41. Orłowski, P.; Kowalczyk, A.; Tomaszewska, E.; Ranoszek-Soliwoda, K.; Węgrzyn, A.; Grzesiak, J.; Celichowski, G.; Grobelny, J.; Eriksson, K.; Krzyzowska, M. Antiviral activity of tannic acid modified silver nanoparticles: Potential to activate immune response in herpes genitalis. Viruses 2018, 10, 524. [CrossRef] [PubMed]

42. De Leo, A.; Arena, G.; Lacanna, E.; Oliviero, G.; Colavita, F.; Mattia, E. Resveratrol inhibits Epstein Barr Virus lytic cycle in Burkitt's lymphoma cells by affecting multiple molecular targets. Antiviral Res. 2012, 96, 196-202. [CrossRef] [PubMed]

43. Colak, M.; Sarzhanova, S.; Yegin, Z.A.; Ozkurt, Z.N.; Fidan, I.; Bozdayi, G. Determination and Role of Epstein-Barr Virus in Patients With Lymphoproliferative Disorders. Clin. Lymphoma Myeloma Leuk. 2021, 21, e488-e492. [CrossRef] [PubMed]

44. Ma, S.-D.; Hegde, S.; Young, K.H.; Sullivan, R.; Rajesh, D.; Zhou, Y.; Jankowska-Gan, E.; Burlingham, W.J.; Sun, X.; Gulley, M.L.; et al. A New Model of Epstein-Barr Virus Infection Reveals an Important Role for Early Lytic Viral Protein Expression in the Development of Lymphomas. J. Virol. 2011, 85, 165-177. [CrossRef] [PubMed]

45. Vasudevan, H.N.; Yom, S.S. Nasopharyngeal Carcinoma and Its Association with Epstein-Barr Virus. Hematol. Oncol. Clin. N. Am. 2021, 35, 963-971. [CrossRef]

46. Lewandowska, H.; Kalinowska, M.; Lewandowski, W.; Stepkowski, T.M.; Brzóska, K. The role of natural polyphenols in cell signaling and cytoprotection against cancer development. J. Nutr. Biochem. 2016, 32, 1-19. [CrossRef] [PubMed]

47. Vestergaard, M.; Ingmer, H. Antibacterial and antifungal properties of resveratrol. Int. J. Antimicrob. Agents 2019, 53, 716-723. [CrossRef]

48. Wu, C.C.; Fang, C.Y.; Hsu, H.Y.; Chen, Y.J.; Chou, S.P.; Huang, S.Y.; Cheng, Y.J.; Lin, S.F.; Chang, Y.; Tsai, C.H.; et al. Luteolin inhibits Epstein-Barr virus lytic reactivation by repressing the promoter activities of immediate-early genes. Antiviral Res. 2016, 132, 99-110. [CrossRef]

49. Nomura, E.; Hosoda, A.; Morishita, H.; Murakami, A.; Koshimizu, K.; Ohigashi, H.; Taniguchi, H. Synthesis of Novel Polyphenols Consisted of Ferulic and Gallic Acids, and Their Inhibitory Effects on Phorbol Ester-Induced Epstein-Barr Virus Activation and Superoxide Generation. Bioorg. Med. Chem. 2002, 10, 1069-1075. [CrossRef]

50. Liu, H.; Chen, H.; Liu, Z.; Le, Z.; Nie, T.; Qiao, D.; Su, Y.; Mai, H.; Chen, Y.; Liu, L. Therapeutic nanovaccines sensitize EBV-associated tumors to checkpoint blockade therapy. Biomaterials 2020, 255, 120158. [CrossRef]

51. Flerlage, T.; Hayden, R.; Cross, S.J.; Dallas, R.; Srinivasan, A.; Tang, L.; Sun, Y.; Maron, G. Rotavirus infection in pediatric allogeneic hematopoietic cell transplant recipients: Clinical course and experience using nitazoxanide and enterally administered immunoglobulins. Pediatr. Infect. Dis. J. 2018, 37, 176-181. [CrossRef] [PubMed]

52. Huang, H.; Liao, D.; Zhou, G.; Zhu, Z.; Cui, Y.; Pu, R. Antiviral activities of resveratrol against rotavirus in vitro and in vivo. Phytomedicine 2020, 77, 153230. [CrossRef] [PubMed]

53. Kwon, H.J.; Kim, H.H.; Ryu, Y.B.; Kim, J.H.; Jeong, H.J.; Lee, S.W.; Chang, J.S.; Cho, K.O.; Rho, M.C.; Park, S.J.; et al. In vitro anti-rotavirus activity of polyphenol compounds isolated from the roots of Glycyrrhiza uralensis. Bioorg. Med. Chem. 2010, 18, 7668-7674. [CrossRef]

54. Cecílio, A.B.; Oliveira, P.D.C.; Caldas, S.; Campana, P.R.V.; Francisco, F.L.; Duarte, M.G.R.; Mendonça, L.D.A.M.; Almeida, V.L.D. Antiviral activity of Myracrodruon urundeuva against rotavirus. Rev. Bras. Farmacogn. 2016, 26, 197-202. [CrossRef]

55. Téllez, M.A.; Téllez, A.N.; Vélez, F.; Ulloa, J.C. In vitro antiviral activity against rotavirus and astrovirus infection exerted by substances obtained from Achyrocline bogotensis (Kunth) DC. (Compositae). BMC Complement. Altern. Med. 2015, 15, 1-10. [CrossRef] [PubMed]

56. Oh, H.M.; Lee, S.W.; Park, M.H.; Kim, M.H.; Ryu, Y.B.; Kim, M.S.; Kim, H.H.; Park, K.H.; Lee, W.S.; Park, S.J.; et al. Norkurarinol Inhibits Toll-Like Receptor 3 (TLR3)-Mediated Pro-inflammatory Signaling Pathway and Rotavirus Replication. J. Pharmacol. Sci. 2012, 118, 161-170. [CrossRef] [PubMed]

57. Seah, I.; Agrawal, R. Can the Coronavirus Disease 2019 (COVID-19) Affect the Eyes? A Review of Coronaviruses and Ocular Implications in Humans and Animals. Ocul. Immunol. Inflamm. 2020, 28, 391-395. [CrossRef] [PubMed]

58. Yi, L.; Li, Z.; Yuan, K.; Qu, X.; Chen, J.; Wang, G.; Zhang, H.; Luo, H.; Zhu, L.; Jiang, P.; et al. Small Molecules Blocking the Entry of Severe Acute Respiratory Syndrome Coronavirus into Host Cells. J. Virol. 2004, 78, 11334-11339. [CrossRef] [PubMed] 
59. Tallei, T.E.; Tumilaar, S.G.; Niode, N.J.; Kepel, B.J.; Idroes, R.; Effendi, Y.; Sakib, S.A.; Emran, T. Bin Potential of Plant Bioactive Compounds as SARS-CoV-2 Main Protease (Mpro) and Spike (S) Glycoprotein Inhibitors: A Molecular Docking Study. Scientifica 2020, 2020, 1-18. [CrossRef] [PubMed]

60. Paraiso, I.L.; Revel, J.S.; Stevens, J.F. Potential use of polyphenols in the battle against COVID-19. Curr. Opin. Food Sci. 2020, 32, 149. [CrossRef]

61. Eskier, D.; Karakülah, G.; Suner, A.; Oktay, Y. RdRp mutations are associated with SARS-CoV-2 genome evolution. PeerJ 2020, 8, e9587. [CrossRef]

62. El-Missiry, M.A.; Fekri, A.; Kesar, L.A.; Othman, A.I. Polyphenols are potential nutritional adjuvants for targeting COVID-19. Phyther. Res. 2021, 35, 2879-2889. [CrossRef]

63. Lin, S.C.; Ho, C.T.; Chuo, W.H.; Li, S.; Wang, T.T.; Lin, C.C. Effective inhibition of MERS-CoV infection by resveratrol. BMC Infect. Dis. 2017, 17, 1-10. [CrossRef]

64. Utomo, R.Y.; Meiyanto, E. Revealing the Potency of Citrus and Galangal Constituents to Halt SARS-CoV-2 Infection. Preprints 2020, 2020030214. Available online: https:/ / www.preprints.org/manuscript/202003.0214/v1 (accessed on 12 June 2021). [CrossRef]

65. Annunziata, G.; Sanduzzi Zamparelli, M.; Santoro, C.; Ciampaglia, R.; Stornaiuolo, M.; Tenore, G.C.; Sanduzzi, A.; Novellino, E. May Polyphenols Have a Role Against Coronavirus Infection? An Overview of in vitro Evidence. Front. Med. 2020, 7, 240. [CrossRef] [PubMed]

66. Diniz, L.R.L.; Da Silva Maia Bezerra Filho, C.; Fielding, B.C.; De Sousa, D.P.; Gil, G. Natural Antioxidants: A Review of Studies on Human and Animal Coronavirus. Oxid. Med. Cell. Longev. 2020, 2020, 1-14. [CrossRef]

67. Muzio, L.L.; Bizzoca, M.E.; Ravagnan, G. New intriguing possibility for prevention of coronavirus pneumonitis: Natural purified polyphenols. Oral Dis. 2020, 1-5. Available online: https:/ / www.ncbi.nlm.nih.gov/pmc/articles/PMC7361353/ (accessed on 12 June 2021). [CrossRef]

68. Mehany, T.; Khalifa, I.; Barakat, H.; Althwab, S.A.; Alharbi, Y.M.; El-Sohaimy, S. Polyphenols as promising biologically active substances for preventing SARS-CoV-2: A review with research evidence and underlying mechanisms. Food Biosci. 2021, 40, 100891. [CrossRef] [PubMed]

69. Richart, S.M.; Li, Y.-L.; Mizushina, Y.; Chang, Y.-Y.; Chung, T.-Y.; Chen, G.-H.; Tzen, J.T.-C.; Shia, K.-S.; Hsu, W.-L. Synergic effect of curcumin and its structural analogue (Monoacetylcurcumin) on anti-influenza virus infection. J. Food Drug Anal. 2018, 26, 1015-1023. [CrossRef]

70. Luganini, A.; Terlizzi, M.E.; Catucci, G.; Gilardi, G.; Maffei, M.E.; Gribaudo, G. The cranberry extract oximacro ${ }^{\circledR}$ exerts in vitro virucidal activity against influenza virus by interfering with hemagglutinin. Front. Microbiol. 2018, 9, 1826. [CrossRef]

71. Lipson, S.M.; Karalis, G.; Karthikeyan, L.; Ozen, F.S.; Gordon, R.E.; Ponnala, S.; Bao, J.; Samarrai, W.; Wolfe, E. Mechanism of Anti-rotavirus Synergistic Activity by Epigallocatechin Gallate and a Proanthocyanidin-Containing Nutraceutical. Food Environ. Virol. 2017, 9, 434-443. [CrossRef]

72. Nagai, E.; Iwai, M.; Koketsu, R.; Sogabe, R.; Morimoto, R.; Suzuki, Y.; Ohta, Y.; Okuno, Y.; Ohshima, A.; Enomoto, T.; et al. Inhibition of influenza virus replication by adlay tea. J. Sci. Food Agric. 2018, 98, 1899-1905. [CrossRef]

73. Makau, J.N.; Watanabe, K.; Mohammed, M.M.D.; Nishida, N. Antiviral Activity of Peanut (Arachis hypogaea L.) Skin Extract Against Human Influenza Viruses. J. Med. Food 2018, 21, 777-784. [CrossRef] [PubMed]

74. Kim, S.; Chung, J.; Lee, S.H.; Yoon, J.H.; Kweon, D.H.; Chung, W.J. Tannic acid-functionalized HEPA filter materials for influenza virus capture. Sci. Rep. 2021, 11, 1-7. [CrossRef]

75. Zhang, M.; Wu, Q.; Chen, Y.; Duan, M.; Tian, G.; Deng, X.; Sun, Y.; Zhou, T.; Zhang, G.; Chen, W.; et al. Inhibition of proanthocyanidin A2 on porcine reproductive and respiratory syndrome virus replication in vitro. PLoS ONE 2018, 13, e0193309. [CrossRef] [PubMed]

76. Medjeldi, S.; Bouslama, L.; Benabdallah, A.; Essid, R.; Haou, S.; Elkahoui, S. Biological activities, and phytocompounds of northwest Algeria Ajuga iva (L) extracts: Partial identification of the antibacterial fraction. Microb. Pathog. 2018, 121, 173-178. [CrossRef]

77. D’angeli, F.; Malfa, G.A.; Garozzo, A.; Volti, G.L.; Genovese, C.; Stivala, A.; Nicolosi, D.; Attanasio, F.; Bellia, F.; Ronsisvalle, S.; et al. Antimicrobial, antioxidant, and cytotoxic activities of juglans regia 1. Pellicle extract. Antibiotics 2021, 10, 159. [CrossRef]

78. Lavoie, S.; Côté, I.; Pichette, A.; Gauthier, C.; Ouellet, M.; Nagau-Lavoie, F.; Mshvildadze, V.; Legault, J. Chemical composition and anti-herpes simplex virus type 1 (HSV-1) activity of extracts from Cornus canadensis. BMC Complement. Altern. Med. 2017, 17, 1-12. [CrossRef]

79. Kim, H.; Lim, C.Y.; Chung, M.S. Magnolia officinalis and Its Honokiol and Magnolol Constituents Inhibit Human Norovirus Surrogates. Foodborne Pathog. Dis. 2021, 18, 24-30. [CrossRef]

80. Suručić, R.; Tubić, B.; Stojiljković, M.P.; Djuric, D.M.; Travar, M.; Grabež, M.; Šavikin, K.; Škrbić, R. Computational study of pomegranate peel extract polyphenols as potential inhibitors of SARS-CoV-2 virus internalization. Mol. Cell. Biochem. 2021, 476, 1179-1193. [CrossRef]

81. Joshi, S.S.; Howell, A.B.; D'Souza, D.H. Antiviral effects of blueberry proanthocyanidins against Aichi virus. Food Microbiol. 2019, 82, 202-208. [CrossRef]

82. Sarwar, M.W.; Riaz, A.; Dilshad, S.M.R.; Al-Qahtani, A.; Nawaz-Ul-Rehman, M.S.; Mubin, M. Structure activity relationship (SAR) and quantitative structure activity relationship (QSAR) studies showed plant flavonoids as potential inhibitors of dengue NS2B-NS3 protease. BMC Struct. Biol. 2018, 18, 1-10. [CrossRef] 
83. Liu, D.; Deng, J.; Joshi, S.; Liu, P.; Zhang, C.; Yu, Y.; Zhang, R.; Fan, D.; Yang, H.; D'Souza, D.H. Monomeric catechin and dimeric procyanidin B2 against human norovirus surrogates and their physicochemical interactions. Food Microbiol. 2018, 76, 346-353. [CrossRef] [PubMed]

84. Khan, M.; Rauf, W.; Fazal-e-Habib, M.R.; Iqbal, M. Screening and identification of bioactive compounds from citrus against non-structural protein 3 protease of hepatitis $C$ virus genotype $3 a$ by fluorescence resonance energy transfer assay and mass spectrometry. World J. Hepatol. 2020, 12, 976-992. [CrossRef]

85. Bisignano, C.; Mandalari, G.; Smeriglio, A.; Trombetta, D.; Pizzo, M.M.; Pennisi, R.; Sciortino, M.T. Almond skin extracts abrogate HSV-1 replication by blocking virus binding to the cell. Viruses 2017, 9, 178. [CrossRef]

86. Grienke, U.; Mair, C.E.; Kirchmair, J.; Schmidtke, M.; Rollinger, J.M. Discovery of Bioactive Natural Products for the Treatment of Acute Respiratory Infections-An Integrated Approach. Planta Med. 2018, 84, 684-695. [CrossRef] [PubMed]

87. Chen, F.; Yang, L.; Huang, Y.; Chen, Y.; Sang, H.; Duan, W.; Yang, J. Isocorilagin, isolated from Canarium album (Lour.) Raeusch, as a potent neuraminidase inhibitor against influenza A virus. Biochem. Biophys. Res. Commun. 2020, 523, 183-189. [CrossRef] [PubMed]

88. Sánchez-Roque, Y.; Ayora-Talavera, G.; Rincón-Rosales, R.; Gutiérrez-Miceli, F.A.; Meza-Gordillo, R.; Winkler, R.; Gamboa-Becerra, R.; Ayora-Talavera, T.D.R.; Ruiz-Valdiviezo, V.M. The flavonoid fraction from Rhoeo discolor leaves acting as antiviral against influenza A virus. Rec. Nat. Prod. 2017, 11, 532-546. [CrossRef]

89. He, Z.; Lian, W.; Liu, J.; Zheng, R.; Xu, H.; Du, G.; Liu, A. Isolation, structural characterization and neuraminidase inhibitory activities of polyphenolic constituents from Flos caryophylli. Phytochem. Lett. 2017, 19, 160-167. [CrossRef]

90. Sekizawa, H.; Ikuta, K.; Ohnishi-Kameyama, M.; Nishiyama, K.; Suzutani, T. Identification of the components in a vaccinium oldhamii extract showing inhibitory activity against influenza virus adsorption. Foods 2019, 8, 172. [CrossRef]

91. Morán-Santibañez, K.; Peña-Hernández, M.A.; Cruz-Suárez, L.E.; Ricque-Marie, D.; Skouta, R.; Vasquez, A.H.; Rodríguez-Padilla, C.; Trejo-Avila, L.M. Virucidal and synergistic activity of polyphenol-rich extracts of seaweeds against measles virus. Viruses 2018, 10, 465. [CrossRef]

92. Joshi, S.; Howell, A.B.; D'Souza, D.H. Blueberry proanthocyanidins against human norovirus surrogates in model foods and under simulated gastric conditions. Food Microbiol. 2017, 63, 263-267. [CrossRef] [PubMed]

93. Singh, S.; Sk, M.F.; Sonawane, A.; Kar, P.; Sadhukhan, S. Plant-derived natural polyphenols as potential antiviral drugs against SARS-CoV-2 via RNA-dependent RNA polymerase (RdRp) inhibition: An in-silico analysis. J. Biomol. Struct. Dyn. 2020, 10, 1-16. [CrossRef] [PubMed]

94. Zhou, M.; Liu, C.; Yang, J.; Niu, D.; Dong, M.; Yang, G.; Li, X.; Hu, Q. Alatains A and B, unique hetero-dimeric polyphenols from Cassia alata and their anti-tobacco mosaic virus activity. Fitoterapia 2020, 147, 104763. [CrossRef] [PubMed]

95. Abdelkhalek, A.; Salem, M.Z.M.; Kordy, A.M.; Salem, A.Z.M.; Behiry, S.I. Antiviral, antifungal, and insecticidal activities of Eucalyptus bark extract: HPLC analysis of polyphenolic compounds. Microb. Pathog. 2020, 147, 104383. [CrossRef]

96. Cao, S.; Realegeno, S.; Pant, A.; Satheshkumar, P.S.; Yang, Z. Suppression of poxvirus replication by resveratrol. Front. Microbiol. 2017, 8, 2196. [CrossRef]

97. Vázquez-Calvo, Á.; de Oya, N.J.; Martín-Acebes, M.A.; Garcia-Moruno, E.; Saiz, J.C. Antiviral properties of the natural polyphenols delphinidin and epigallocatechin gallate against the flaviviruses West Nile Virus, Zika Virus, and Dengue Virus. Front. Microbiol. 2017, 8, 1314. [CrossRef]

98. Gaudry, A.; Bos, S.; Viranaicken, W.; Roche, M.; Krejbich-Trotot, P.; Gadea, G.; Desprès, P.; El-Kalamouni, C. The flavonoid isoquercitrin precludes initiation of Zika virus infection in human cells. Int. J. Mol. Sci. 2018, 19, 1093. [CrossRef]

99. Lin, S.C.; Zhang, X.; Lehman, C.W.; Pan, H.C.; Wen, Y.; Chen, S.Y. A natural botanical product, resveratrol, effectively suppresses vesicular stomatitis virus infection in vitro. Plants 2021, 10, 1231. [CrossRef]

100. Kandeil, A.; Mostafa, A.; Kutkat, O.; Moatasim, Y.; Al-karmalawy, A.A.; Rashad, A.A.; Kayed, A.E.; Kayed, A.E.; El-Shesheny, R.; Kayali, G.; et al. Bioactive polyphenolic compounds showing strong antiviral activities against severe acute respiratory syndrome coronavirus 2. Pathogens 2021, 10, 758. [CrossRef]

101. Zhang, T.; Lo, C.Y.; Xiao, M.; Cheng, L.; Pun Mok, C.K.; Shaw, P.C. Anti-influenza virus phytochemicals from Radix Paeoniae Alba and characterization of their neuraminidase inhibitory activities. J. Ethnopharmacol. 2020, 253, 112671. [CrossRef] [PubMed]

102. Yadav, P.; Choudhury, S.; Barua, S.; Khandelwal, N.; Kumar, N.; Shukla, A.; Garg, S.K. Polyalthia longifolia leaves methanolic extract targets entry and budding of viruses-an in vitro experimental study against paramyxoviruses. J. Ethnopharmacol. 2020, 248, 112279. [CrossRef] [PubMed]

103. Choi, J.G.; Lee, H.; Kim, Y.S.; Hwang, Y.H.; Oh, Y.C.; Lee, B.; Moon, K.M.; Cho, W.K.; Ma, J.Y. Aloe vera and its Components Inhibit Influenza A Virus-Induced Autophagy and Replication. Am. J. Chin. Med. 2019, 47, 1307-1324. [CrossRef] [PubMed]

104. Trujillo-Correa, A.I.; Quintero-Gil, D.C.; Diaz-Castillo, F.; Quiñones, W.; Robledo, S.M.; Martinez-Gutierrez, M. In vitro and in silico anti-dengue activity of compounds obtained from Psidium guajava through bioprospecting. BMC Complement. Altern. Med. 2019, 19, 1-16. [CrossRef] [PubMed]

105. Li, Y.; Yang, D.; Jia, Y.; He, L.; Li, J.; Yu, C.; Liao, C.; Yu, Z.; Zhang, C. Research Note: Anti-inflammatory effects and antiviral activities of baicalein and chlorogenic acid against infectious bursal disease virus in embryonic eggs. Poult. Sci. 2021, 100, 100987. [CrossRef] [PubMed] 
106. Zhu, Y.; Gu, X.; Zhang, M.; Lv, X.; Zhang, C.; Li, J.; Hu, Z.; Wu, Q.; Zhang, R.; Wei, J.; et al. Epigallocatechin-3-gallate exhibits antiviral effects against the duck Tembusu virus via blocking virus entry and upregulating type I interferons. Poult. Sci. 2021, 100, 100989. [CrossRef] [PubMed]

107. Liu, Y.; Yao, W.; Si, L.; Hou, J.; Wang, J.; Xu, Z.; Li, W.; Chen, J.; Li, R.; Li, P.; et al. Chinese herbal extract Su-duxing had potent inhibitory effects on both wild-type and entecavir-resistant hepatitis B virus (HBV) in vitro and effectively suppressed HBV replication in mouse model. Antiviral Res. 2018, 155, 39-47. [CrossRef]

108. Xu, M.J.; Liu, B.J.; Wang, C.I.; Wang, G.H.; Tian, Y.; Wang, S.H.; Li, J.; Li, P.Y.; Zhang, R.H.; Wei, D.; et al. Epigallocatechin-3-gallate inhibits TLR4 signaling through the 67-kDa laminin receptor and effectively alleviates acute lung injury induced by H9N2 swine influenza virus. Int. Immunopharmacol. 2017, 52, 24-33. [CrossRef] [PubMed]

109. Yugandhar, P.; Kumar, K.K.; Neeraja, P.; Savithramma, N. Isolation, characterization and in silico docking studies of synergistic estrogen receptor $\alpha$ anticancer polyphenols from Syzygium alternifolium (Wt.) walp. J. Intercult. Ethnopharmacol. 2017, 6, 296-310. [CrossRef]

110. Esatbeyoglu, T.; Rodríguez-Werner, M.; Winterhalter, P. Fractionation and isolation of polyphenols from Aronia melanocarpa by countercurrent and membrane chromatography. Eur. Food Res. Technol. 2017, 243, 1261-1275. [CrossRef]

111. Sun, S.; Huang, S.; Shi, Y.; Shao, Y.; Qiu, J.; Sedjoah, R.C.A.A.; Yan, Z.; Ding, L.; Zou, D.; Xin, Z. Extraction, isolation, characterization and antimicrobial activities of non-extractable polyphenols from pomegranate peel. Food Chem. 2021, $351,129232$. [CrossRef]

112. Yathzamiry, V.G.D.; Cecilia, E.G.S.; Antonio, M.C.J.; Daniel, N.F.S.; Carolina, F.G.A.; Alberto, A.V.J.; Raúl, R.H. Isolation of Polyphenols from Soursop (Annona muricata L.) Leaves Using Green Chemistry Techniques and their Anticancer Effect. Brazilian Arch. Biol. Technol. 2021, 64, 1-15. [CrossRef]

113. Mansour, A.; Celano, R.; Mencherini, T.; Picerno, P.; Piccinelli, A.L.; Foudil-Cherif, Y.; Csupor, D.; Rahili, G.; Yahi, N.; Nabavi, S.M.; et al. A new cineol derivative, polyphenols and norterpenoids from Saharan myrtle tea (Myrtus nivellei): Isolation, structure determination, quantitative determination and antioxidant activity. Fitoterapia 2017, 119, 32-39. [CrossRef]

114. Torres, C.A.; Sturla, M.A.; Romero, A.M.; Judis, M.A. Bioguided isolation of antimicrobial polyphenols from Cuspidaria convoluta leaves and their synergistic effect with antibiotics. Asian Pac. J. Trop. Biomed. 2019, 9, 434-442. [CrossRef]

115. Rahman, S.; Helleur, R.; MacQuarrie, S.; Papari, S.; Hawboldt, K. Upgrading and isolation of low molecular weight compounds from bark and softwood bio-oils through vacuum distillation. Sep. Purif. Technol. 2018, 194, 123-129. [CrossRef]

116. Farías-Campomanes, A.M.; Rostagno, M.A.; Coaquira-Quispe, J.J.; Meireles, M.A.A. Supercritical fluid extraction of polyphenols from lees: Overall extraction curve, kinetic data and composition of the extracts. Bioresour. Bioprocess. 2015, 2, 45. [CrossRef]

117. Ameer, K.; Shahbaz, H.M.; Kwon, J.-H. Green Extraction Methods for Polyphenols from Plant Matrices and Their Byproducts: A Review. Compr. Rev. Food Sci. Food Saf. 2017, 16, 295-315. [CrossRef] [PubMed]

118. Wang, Z.; Peng, S.; Peng, M.; Wang, C. Isolation of polyphenol compounds from olive waste and inhibition of their derivatives for $\alpha$-glucosidase and $\alpha$-amylase. Nat. Prod. Res. 2020, 34, 2398-2402. [CrossRef]

119. Barrientos, R.E.; Simirgiotis, M.J.; Palacios, J.; Paredes, A.; Bórquez, J.; Bravo, A.; Cifuentes, F. Chemical fingerprinting, isolation and characterization of polyphenol compounds from Heliotropium taltalense (Phil.) I.M. Johnst and its endothelium-dependent vascular relaxation effect in rat aorta. Molecules 2020, 25, 3105. [CrossRef]

120. Mieres-Castro, D.; Schmeda-Hirschmann, G.; Theoduloz, C.; Gómez-Alonso, S.; Pérez-Navarro, J.; Márquez, K.; Jiménez-Aspee, F. Antioxidant activity and the isolation of polyphenols and new iridoids from Chilean Gaultheria phillyreifolia and G. poeppigii berries. Food Chem. 2019, 291, 167-179. [CrossRef]

121. Ma, Y.; Shang, Y.; Liu, F.; Zhang, W.; Wang, C.; Zhu, D. Convenient isolation of strictinin-rich tea polyphenol from Chinese green tea extract by zirconium phosphate. J. Food Drug Anal. 2018, 26, 100-106. [CrossRef]

122. Dahmoune, F.; Nayak, B.; Moussi, K.; Remini, H.; Madani, K. Optimization of microwave-assisted extraction of polyphenols from Myrtus communis L. leaves. Food Chem. 2015, 166, 585-595. [CrossRef]

123. Corazza, G.O.; Bilibio, D.; Zanella, O.; Nunes, A.L.; Bender, J.P.; Carniel, N.; dos Santos, P.P.; Priamo, W.L. Pressurized liquid extraction of polyphenols from Goldenberry: Influence on antioxidant activity and chemical composition. Food Bioprod. Process. 2018, 112, 63-68. [CrossRef]

124. Vergara-Salinas, J.R.; Bulnes, P.; Zúñiga, M.C.; Pérez-Jiménez, J.; Torres, J.L.; Mateos-Martín, M.L.; Agosin, E.; Pérez-Correa, J.R. Effect of pressurized hot water extraction on antioxidants from grape pomace before and after enological fermentation. J. Agric. Food Chem. 2013, 61, 6929-6936. [CrossRef] [PubMed]

125. Periasamy. Manikandan, A..; Akila, S.; Prabu, K. Production of Polyphenol from Phyllanthus Emblica using Soxhlet Extraction Process. Int. J. Recent Technol. Eng. 2019, 8, 5010-5012. [CrossRef]

126. Socas-Rodríguez, B.; Torres-Cornejo, M.V.; Álvarez-Rivera, G.; Mendiola, J.A. Deep Eutectic Solvents for the Extraction of Bioactive Compounds from Natural Sources and Agricultural By-Products. Appl. Sci. 2021, 11, 4897. [CrossRef]

127. Paiva, A.; Craveiro, R.; Aroso, I.; Martins, M.; Reis, R.L.; Duarte, A.R.C. Natural Deep Eutectic Solvents-Solvents for the 21st Century. ACS Sustain. Chem. Eng. 2014, 2, 1063-1071. [CrossRef]

128. Dai, Y.; Witkamp, G.-J.; Verpoorte, R.; Choi, Y.H. Natural Deep Eutectic Solvents as a New Extraction Media for Phenolic Metabolites in Carthamus tinctorius L. Anal. Chem. 2013, 85, 6272-6278. [CrossRef]

129. Wan Mahmood, W.M.A.; Lorwirachsutee, A.; Theodoropoulos, C.; Gonzalez-Miquel, M. Polyol-Based Deep Eutectic Solvents for Extraction of Natural Polyphenolic Antioxidants from Chlorella vulgaris. ACS Sustain. Chem. Eng. 2019, 7, 5018-5026. [CrossRef] 